\title{
Mature Dendritic Cells May Promote High-Avidity Tuning of Vaccine T Cell Responses
}

\section{OPEN ACCESS}

Edited by:

Graham Pawelec,

University of Tübingen, Germany

Reviewed by:

Markus Philipp Radsak,

Johannes Gutenberg University Mainz,

Germany

Michele De Palma

École Polytechnique Fédérale de

Lausanne, Switzerland

*Correspondence:

Peter S. Kim

peter.kim@sydney.edu.au

${ }^{t}$ These authors share first authorship

FThese authors have contributed equally to this work

Specialty section:

This article was submitted to Vaccines and Molecular Therapeutics, a section of the journal

Frontiers in Immunology

Received: 17 July 2020 Accepted: 05 October 2020 Published: 30 October 2020

Citation: Kumbhari A, Egelston CA, Lee PP and Kim PS (2020) Mature Dendritic Cells May Promote High-Avidity Tuning of Vaccine $T$ Cell Responses.

Front. Immunol. 11:584680. doi: 10.3389/fimmu.2020.584680

\author{
Adarsh Kumbhari ${ }^{1 \dagger}$, Colt A. Egelston ${ }^{2 \dagger}$, Peter P. Lee ${ }^{2 \ddagger}$ and Peter S. Kim ${ }^{1 \neq \neq}$ \\ 1 School of Mathematics and Statistics, University of Sydney, Sydney, NSW, Australia, 2 Department of Immuno-Oncology, \\ Beckman Research Institute, City of Hope, Duarte, CA, United States
}

Therapeutic vaccines can elicit tumor-specific cytotoxic T lymphocytes (CTLs), but durable reductions in tumor burden require vaccines that stimulate high-avidity CTLs. Recent advances in immunotherapy responses have led to renewed interest in vaccine approaches, including dendritic cell vaccine strategies. However, dendritic cell requirements for vaccines that generate potent anti-tumor T-cell responses are unclear. Here we use mathematical modeling to show that, counterintuitively, increasing levels of immature dendritic cells may lead to selective expansion of high-avidity CTLs. This finding is in contrast with traditional dendritic cell vaccine approaches that have sought to harness ex vivo generated mature dendritic cells. We show that the injection of vaccine antigens in the context of increased numbers of immature dendritic cells results in a decreased overall peptide:MHC complex load that favors high-avidity CTL activation and expansion. Overall, our results provide a firm basis for further development of this approach, both alone and in combination with other immunotherapies such as checkpoint blockade.

Keywords: T-cell avidity, DC vaccines, cancer vaccines, immature DCs, mathematical model

\section{INTRODUCTION}

In principle, the immune system can eliminate cancer cells by the activation and expansion of cancer-specific cytotoxic T lymphocytes (CTLs). Immune checkpoint blockade (ICB) immunotherapies, which release $\mathrm{T}$ cells from various negative regulatory pathways, have demonstrated impressive clinical successes and have become standard-of-care for many malignancies (1). However, the response to ICB seems to require the pre-existence of anti-tumor $\mathrm{T}$ cells (2). Vaccine approaches to generate tumor-specific $\mathrm{T}$ cells offer a potential solution towards generating a sufficient anti-tumor T cell response. Dendritic cell (DC) vaccines in particular, offer a means to activate and expand tumor-specific $\mathrm{T}$ cells (3). Here we discuss the impact of DC maturation status on vaccine design strategies.

CTLs detect cancer cells by $\mathrm{T}$ cell receptor (TCR) recognition of peptides displayed by a major histocompatibility complex (pMHC) on the surface of target cancer cells. Each TCR-pMHC interaction occurs at a particular strength-affinity-with multiple TCR-pMHC interactions occurring for each CTL-target cell interaction. While affinity is a measure of individual TCR-pMHC bonds, avidity is an overall measure of the strength of the TCR-pMHC interaction and as such, depends on the amount of 
pMHC expressed by antigen presenting cells (4). Importantly, T cell avidity determines the likelihood of successful lysis (5).

Therapeutic peptide vaccines aim to capitalize on the cancerkilling ability of CTLs. Initial results of peptide-based vaccines showed the ability to elicit significant numbers of antigen-specific CTLs, but often lacked measurable clinical successes (6-8). Recent progress in vaccine construction and combinatorial strategies with other immunotherapy agents has shown renewed promise for therapeutic peptide vaccines (3). Our work suggests that the dose and modality of peptide vaccines are key considerations for the design of future clinical interventions.

Early studies of cancer-specific CTLs showed that high-avidity TCRs are necessary to effectively lyse cancer cells that express native antigens at low levels (9). Preferentially selecting for highavidity CTLs, however, is difficult. Regarding vaccines targeting cancer-associated antigens (CAA), thymic education of CTLs may likely have removed high-avidity $\mathrm{T}$ cells from the $\mathrm{T}$-cell repertoire via negative selection (10). As a result, primarily low-avidity CTLs are left to respond to CAA-targeting vaccines. Beyond CAA, recent therapeutic vaccine efforts have focused on targeting somatic mutation-derived neo-antigens $(11,12)$. As yet, neo-antigen vaccines have largely focused on peptides sought to elicit high affinity TCR responses but have not yet explored the impact of dosage on $\mathrm{T}$-cell repertoire response to the vaccine $(13,14)$. For both CAA and neo-antigen targeting vaccines, standard dosages typically involve high antigen loads that may non-discriminately favor the expansion of both high and low avidity CTLs. However, lowering the dosage of peptides for vaccination yields sub-therapeutically relevant levels of CTL (15). Together, this highlights the need for further understanding of antigen dosage and context for efficacious vaccine design.

We previously showed that therapeutic vaccine designs were sensitive to DC-associated parameters (16). Given that DCs, which present antigen on their cell surface along with co-stimulatory molecules, facilitate CTL activation, we hypothesized that modulation of DC and peptide dosing could enhance an anticancer immune response. We show that by increasing the number of immature DCs (iDCs), the average DC antigen load is lowered, which in turn selects for the expansion of high-avidity CTLs. This observation suggests traditional DC vaccine approaches that intravenously inject ex vivo matured $\mathrm{DCs}(\mathrm{mDCs})$ may need to be reconsidered in favor of an injection of iDCs paired with injection of peptide and adjuvant $(3,17)$. Our work suggests that combinatorial therapy with vaccine antigens and increased immature DCs, either by ex vivo generation or stimulated in vivo, may have efficacy. Thus, our findings suggest an approach that could improve already existing immune-based cancer therapies for increased and more durable clinical responses.

\section{MATERIAL AND METHODS}

We previously developed a mathematical model to study how vaccine-induced avidity selection affects tumor clearance (16). This model was calibrated to ex vivo human data from Chung et al. (18) and then validated against data from $(19,20)$. Here, we extend this model to show that induction of immature DCs may improve current treatments by eliciting high-avidity CTLs. What follows is a brief description of our previously published model. We primarily use parameter estimates from the literature (see Table 1 and the references therein) and estimates generated from our prior analysis of ex vivo human data.

\section{Basic Model}

The model consists of three major components: the activation and maturation of DCs (Eqs 1-8); the activation and proliferation of T cells (Eqs 9-16); and the lysis and trogocytosis-mediated MHC stripping of cancer cells by effector CTLs (Eqs 23-25). Figure 1 depicts a schematic of these interactions.

\section{Dendritic Cells}

To model the activation and maturation of DCs at the injection site (the volume of which is $\mathrm{V}_{\text {tissue }}$ ), we consider several populations: $P$, the concentration of vaccine peptides; $A$, the concentration of vaccine adjuvant; $I$, the concentration of immature DCs; $S$, the concentration of semi-mature or "tolerizing" DCs; and $M_{j}$, the concentration of maturing DCs presenting $j$ vaccine-associated pMHCs, where $j$ can vary between zero and $N$. In modelling the interactions between these populations, we assume that immature DCs become semi-mature in the presence of peptide antigen, various danger signals, and tissue-derived immunogenic signals $(57,58)$. Once in this semi-mature state, we assume DC maturation occurs as a result of vaccine adjuvant. DC maturation signals may in turn affect T-cell priming and activation (19). As a simplifying assumption, we assume that the strategy to optimize DC maturation is successful. That is, we do not model the pharmacodynamics of the vaccine adjuvant. Next, we model the interactions between these populations with an ODE system:

Change in vaccine peptide concentration:

$$
\frac{d P}{d t}=\underbrace{u(t)}_{\begin{array}{c}
\text { Vaccine } \\
\text { injection }
\end{array}}-\underbrace{d_{P} P}_{\text {Vaccine turnover }}-\underbrace{k_{P i} P I}_{\text {Uptake by } i D C s}-\underbrace{k_{P} P \sum_{j=0}^{N} M_{j}}_{\text {Uptake by } m D C s}-\underbrace{k_{P \phi} P,}_{\begin{array}{c}
\text { Turnover due to } \\
\text { macrophage uptake }
\end{array}}
$$

Change in adjuvant concentration:

$$
\frac{d A}{d t}=\underbrace{a(t)}_{\text {Adjuvant injection }}-\underbrace{k_{P i} A I}_{\text {Uptake by iDCs }}-\underbrace{d_{A} A}_{\text {Adjuvant washout }}-\underbrace{k_{P \phi} A,}_{\begin{array}{c}
\text { Turnover due to } \\
\text { macrophage uptake }
\end{array}}
$$

Change in immature DC concentration:

$$
\frac{d I}{d t}=\underbrace{s_{D}}_{i D C \text { supply }}-\underbrace{\delta_{D} I}_{i D C \text { turnover }}-\underbrace{k_{D} \frac{P}{\chi+P} I}_{i D C \text { activation }}
$$

Change in semi-mature/tolerized DC concentration:

$$
\frac{d S}{d t}=\underbrace{k_{D} \frac{P}{\chi+P} I}_{\text {iDC activation }}-\underbrace{d_{D} S}_{\text {Turnover }}-\underbrace{k_{S} \frac{A}{A+A_{0}} S}_{\text {Maturation due to }},
$$


TABLE 1 | Estimates that are characterized by human data are marked with a superscript $H$, while estimates based on murine data are marked with a superscript $M$.

\begin{tabular}{|c|c|c|c|}
\hline Parameter & Description & Estimate & Reference \\
\hline$d_{p}$ & Peptide decay rate ${ }^{\vee}$ & 6.16/day & $(21)$ \\
\hline$k_{P}$ & Mature DC uptake rate ${ }^{\mathrm{HV}}$ & $\begin{array}{c}3 \times 10^{-2} \\
(\mathrm{k} / \mu \mathrm{L})^{-1} / \text { day }\end{array}$ & $(22)$ \\
\hline$k_{P i}$ & Immature DC uptake rate $\mathrm{MV}$ & $\begin{array}{l}6.84 \times 10^{-2} \\
(\mathrm{k} / \mu \mathrm{L})^{-} / \text {day }\end{array}$ & (23) \\
\hline$k_{P \phi}$ & $\begin{array}{l}\text { Vaccine clearance rate due to } \\
\text { tissue macrophages } \mathrm{MV}\end{array}$ & $3.1875 /$ day & $(24)$ \\
\hline$\delta_{D}$ & Immature DC decay rate ${ }^{\mathrm{HV}}$ & $5 \times 10^{-2} /$ day & $(25)$ \\
\hline$S_{D}$ & Immature DC supply rate & $\delta_{D} l(0)$ & $\begin{array}{l}\text { Steady } \\
\text { state }\end{array}$ \\
\hline$I(0)$ & Immature DC concentration & $5.9976 \mathrm{k} / \mu \mathrm{L}$ & (26) \\
\hline$d_{A}$ & Adjuvant washout rate ${ }^{M}$ & 0.396/day & $(27)$ \\
\hline$k_{S}$ & $\begin{array}{l}\text { Semi-matured/tolerized DC } \\
\text { maturation rate }\end{array}$ & $5 \times 10^{6} /$ day & Estimate \\
\hline$A_{0}$ & Adjuvant saturation constant & $10^{4} \mathrm{ng} / \mathrm{mL}$ & Estimate \\
\hline$d_{D}$ & Mature DC decay rate ${ }^{\mathrm{HV}}$ & 0.33/day & (25) \\
\hline$\chi$ & $\begin{array}{l}\text { Concentration of non-vaccine- } \\
\text { associated proteins }{ }^{H}\end{array}$ & $7 \times 10^{7} \mathrm{ng} / \mathrm{mL}$ & (28) \\
\hline$k_{D}$ & Mature DC presentation rate ${ }^{\mathrm{MV}}$ & $\begin{array}{c}2.4 \times 10^{5} \\
\text { pMHCs/day }\end{array}$ & $(29,30)$ \\
\hline$d_{m}$ & pMHC degradation rate ${ }^{\mathrm{MV}}$ & 2.9/day & (31) \\
\hline$N$ & $\begin{array}{l}\text { (Computational) maximum } \\
\text { number of vaccine-associated } \\
\text { pMHCs on a maturing DC }\end{array}$ & 700 & (16) \\
\hline J & Number of avidity levels & 20 & (16) \\
\hline$d_{N} N(0)$ & Naive CTL supply rate & & $\begin{array}{l}\text { Steady } \\
\text { state }\end{array}$ \\
\hline$S_{H}$ & Naive helper $T$ cell supply rate & $d_{N H} N^{H}(0)$ & $\begin{array}{l}\text { Steady } \\
\text { state }\end{array}$ \\
\hline$S_{R}$ & Naive nTreg supply rate & $d_{N R} N_{R}(0)$ & $\begin{array}{l}\text { Steady } \\
\text { state }\end{array}$ \\
\hline$d_{N}$ & Naive CTL egress rate ${ }^{M}$ & 1.2/day & (32) \\
\hline$d_{N H}$ & $\begin{array}{l}\text { Naive helper T cell egress } \\
\text { rate }^{M}\end{array}$ & 2.2/day & (32) \\
\hline$d_{N R}$ & Naive nTreg turnover rate ${ }^{M}$ & $2.2 \times 10^{-3} /$ day & (33) \\
\hline$N(0)$ & $\begin{array}{l}\text { Initial naive CTL } \\
\text { concentration }^{\mathrm{M}}\end{array}$ & $7.6 \times 10^{-3} \mathrm{k} / \mu \mathrm{L}$ & $(34-37)$ \\
\hline$N^{H}(0)$ & $\begin{array}{l}\text { Initial naive helper T cell } \\
\text { concentration }{ }^{\mathrm{M}}\end{array}$ & $0.0571 \mathrm{k} / \mu \mathrm{L}$ & $(34,38)$ \\
\hline$N_{R}(0)$ & $\begin{array}{l}\text { Initial naive } \mathrm{nTreg} \\
\text { concentration }^{\mathrm{M}}\end{array}$ & $0.05 \times N^{H}(0)$ & (39) \\
\hline$R_{\mathrm{LH}}$ & $\begin{array}{l}\text { Ratio of low-high avidity naive } \\
\text { CTLs }\end{array}$ & 100 & Assumption \\
\hline$n_{R}$ & Number of nTreg divisions ${ }^{H V}$ & 6 & $(40)$ \\
\hline$k_{\mathrm{DC}}$ & $\begin{array}{l}\text { Naive CTL-DC interaction } \\
\text { rate }^{\mathrm{M}}\end{array}$ & $0.4(\mathrm{k} / \mu \mathrm{L})^{-1} /$ day & (34) \\
\hline$\tau_{m}$ & DC migration time ${ }^{M}$ & 0.75 days & (34) \\
\hline$V_{\text {tissue }}$ & Volume of tissue site & $1000 \mu \mathrm{L}$ & (16) \\
\hline$V_{\mathrm{LN}}$ & Volume of lymph node ${ }^{M}$ & $4.2 \mu \mathrm{L}$ & (34) \\
\hline$n_{H}$ & $\begin{array}{l}\text { Number of helper T cell } \\
\text { divisions } \mathrm{HV}\end{array}$ & 10 & $(41)$ \\
\hline$\tau_{a}$ & $T$ cell division time ${ }^{M}$ & 1 day & $(38,42)$ \\
\hline$d_{H}$ & $\begin{array}{l}\text { Effector helper } T \text { cell decay } \\
\text { rate }^{H}\end{array}$ & $0.008 /$ day & (43) \\
\hline$n_{T}$ & Number of CTL divisions ${ }^{M}$ & 15 & $\begin{array}{c}(42,44- \\
47)\end{array}$ \\
\hline$d_{T}$ & Effector CTL decay rate ${ }^{H}$ & 0.009/day & (43) \\
\hline$\varphi_{0}$ & Antigen saturation constant & $5 \times 10^{3} \mathrm{ng} / \mathrm{mL}$ & (16) \\
\hline$r_{1}$ & $\begin{array}{l}\text { Secretion rate of growth signal } \\
\text { by CTLs }\end{array}$ & 0.1/day & $(16)$ \\
\hline
\end{tabular}

(Continued)
TABLE 1 | Continued

\begin{tabular}{|c|c|c|c|}
\hline Parameter & Description & Estimate & Reference \\
\hline$r_{2}$ & $\begin{array}{l}\text { Secretion rate of growth signal } \\
\text { by helper } T \text { cells }\end{array}$ & 1/day & $(16)$ \\
\hline$d_{G}$ & Growth factor decay rate ${ }^{\mathrm{H}}$ & 144.4/day & (48) \\
\hline$k_{G}$ & $\begin{array}{l}T \text { cell-growth factor interaction } \\
\text { rate }\end{array}$ & $0.1(\mathrm{k} / \mu \mathrm{L})^{-1} /$ day & (16) \\
\hline$k_{R}$ & iTreg differentiation rate & 0.2/day & (16) \\
\hline$d_{R}$ & iTreg decay rate ${ }^{\mathrm{H}}$ & $0.083 /$ day & $(49,50)$ \\
\hline$d_{R N}$ & Effector nTreg decay rate ${ }^{H}$ & 0.063/day & $(50)$ \\
\hline$\mu$ & CTL-Treg interaction rate ${ }^{\mathrm{H}}$ & $5(\mathrm{k} / \mu \mathrm{L})^{-1} /$ day & (16) \\
\hline K & $\begin{array}{l}\text { (Computational) maximum } \\
\text { number of cognate pMHCs } \\
\text { expressed on cancer cell }\end{array}$ & 295 & $(16)$ \\
\hline$\gamma$ & Growth rate of melanomas ${ }^{\mathrm{H}}$ & 0.0185/day & $(51-53)$ \\
\hline$\kappa$ & $\begin{array}{l}\text { Carrying capacity of } \\
\text { melanomas }^{M}\end{array}$ & $736 \mathrm{k} / \mu \mathrm{L}$ & (54) \\
\hline$\alpha$ & pMHC regeneration rate $\mathrm{MV}$ & 8.4/day & $(55,56)$ \\
\hline$k_{T}$ & Tumor-CTL interaction rate $\mathrm{HV}$ & $16.1(\mathrm{k} / \mu \mathrm{L})^{-1} /$ day & Estimate \\
\hline$p_{T}$ & Probability of trogocytosis $\mathrm{HV}$ & 0.7 & Estimate \\
\hline$\omega_{1}$ & $\begin{array}{l}\text { Lysis likelihood for lowest } \\
\text { avidity }(j=1) \mathrm{CTL}\end{array}$ & 0.28 & Estimate \\
\hline$\omega_{j}$ & $\begin{array}{l}\text { Lysis likelihood for highest } \\
\text { avidity }(j=J) \text { CTL HV }\end{array}$ & 0.96 & Estimate \\
\hline$C_{\text {init }}$ & Initial cancer concentration & $0.05 \mathrm{k} / \mu \mathrm{L}$ & $(16,18)$ \\
\hline
\end{tabular}

Additionally, estimates that are based on cell culture data are marked with a superscript $V$. Finally, the unit ' $k$ ' denotes $10^{3}$ cells.

Change in mature DC concentration:

$$
\begin{gathered}
\frac{d M_{0}}{d t}=-k_{D} \frac{P}{\chi+P} M_{0}+d_{m} M_{1}-d_{D} M_{0}, \\
\frac{d M_{1}}{d t}=\underbrace{k_{S} \frac{A}{A+A_{0}} S}_{\text {Maturation due to }}+\underbrace{k_{D} \frac{P}{\chi+P}\left(M_{0}-M_{1}\right)}_{\text {adjuvant }} \\
+\underbrace{d_{m}\left(2 M_{2}-M_{1}\right)}_{\text {pMHC presentation }}-\underbrace{d_{D} M_{1}}_{m D C \text { turnover }},
\end{gathered}
$$

$$
\begin{gathered}
\frac{d M_{j}}{d t}=\underbrace{k_{D} \frac{P}{\chi+P}\left(M_{j-1}-M_{j}\right)}_{\text {pMHC presentation }}+\underbrace{d_{m}\left((j+1) M_{j+1}-j M_{j}\right)}_{\text {pMHC turnover }}-\underbrace{d_{D} M_{j}}_{\text {mDC turnover }}, \text { (7) } \\
\text { for } j=2, \ldots, N-1, \\
\frac{d M_{N}}{d t}=k_{D} \frac{P}{\chi+P} M_{N-1}-N d_{m} M_{N}-d_{D} M_{N} .
\end{gathered}
$$

In Equation 1, vaccine peptides are injected intramuscularly at rate $u(\mathrm{t})$, decay at rate $d_{p}$, taken up by immature DCs at rate $k_{P i}$, taken up by mature DCs at rate $k_{p}$, and are competitively diminished due to consumption by tissue macrophages at rate $k_{P \phi}$ (note that we do not model these macrophages in our study). Here, we assume that iDCs have a greater antigen uptake rate than mDCs $(59,60)$. In Equation 2, vaccine adjuvants are injected intramuscularly at rate $a(t)$, taken up by immature 


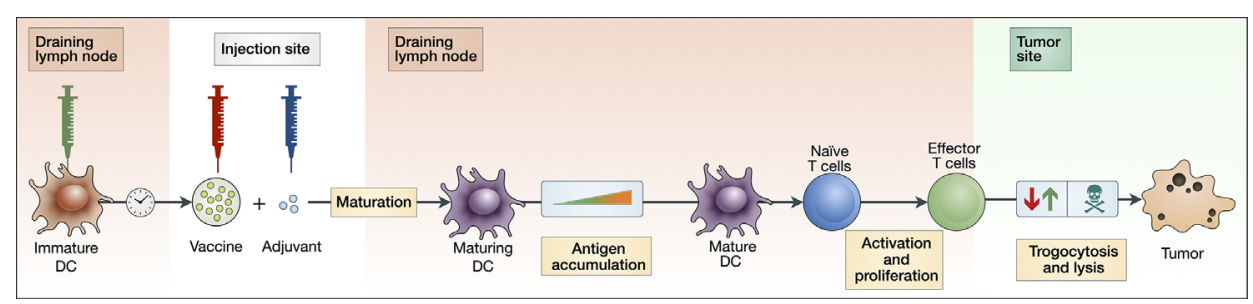

FIGURE 1 | Block diagram depicting key aspects of our theoretical vaccination model. An injection of peptide vaccine is given intramuscularly with adjuvant. Immature DCs are injected intranodally, prompting an accumulation of antigen by maturing DCs. These maturing DCs then migrate and activate naive T cells in the lymph node, which then proliferate into effector T cells. Effector T cells can both strip peptides off the surface of cancer cells via trogocytosis and kill cancer cells.

DCs at rate $k_{P i}$, washed out at rate $d_{A}$, and are lost due to consumption by splenic macrophages at rate $k_{P \phi}$. In Equation 3, immature DCs are supplied at rate $s_{D}$, decay at rate $\delta_{D}$ and become semi-mature and acquire vaccine peptides at rate $k_{D} \frac{P}{\chi+P}$. Here, $k_{D}$ is the rate of peptide presentation, $\chi$ is the concentration of non-vaccine peptides, and $\frac{P}{\chi+P}$ is the proportion of peptides presented that are vaccine specific.

In Equation 4, we assume that semi-mature DCs, $S$, turnover at a rate comparable to mature DCs $d_{D}$, and mature due to adjuvant at rate $k_{S} \frac{A}{A+A_{0}}$. Here, $k_{S}$ is the maturation rate due to adjuvant and $A_{0}$ is a adjuvant-saturation constant that ensures that for large adjuvant doses, the DC maturation tapers off. In the absence of adjuvant, however, these semi-mature DCs are unlikely to produce a functional $\mathrm{T}$ cell response (61). Thus, for the purposes of this study we do not track $\mathrm{T}$ cells that become tolerized as a result of these semi-mature/tolerized DCs.

In Eqs 5 and 6, newly matured DCs initially enter the mature DC population presenting one vaccine peptide with subsequent peptides presented at rate $k_{D} \frac{P}{\chi+P}$ as described above. Additionally, surface peptides degrade at rate $d_{m}$, which is proportional to the number of presented peptides, $j$. Finally, mature DCs decay at rate $d_{D}$. Here, we assume that mature DCs decay faster than iDCs (62).

\section{T Cells}

To model the activation and proliferation of $\mathrm{T}$ cells both at the lymph node (the volume of which is $V_{\mathrm{LN}}$ ) and at the tumor site, we first model avidity as a spectrum that varies from $j=1$ to $j=J$, corresponding to the lowest and highest avidity states respectively. We then consider several populations: $N_{j}$, the concentration of naive CTLs of avidity $j ; N_{j}^{H}$, the concentration of naive helper T cells of avidity $j ; N_{R}$, the concentration of naive natural regulatory T cells; $T_{j}$, the concentration of effector CTLs of avidity $j ; H_{j}$, the concentration of effector helper T cells of avidity $j ; R$, the concentration of induced regulatory $\mathrm{T}$ cells; $R_{N}$, the concentration of effector natural regulatory $\mathrm{T}$ cells; and $G$, the concentration of positive growth factors. The interactions between these populations are then modelled with an ODE system:

Change in naive helper $\mathrm{T}$ cell concentration:

$$
\frac{d N_{j}}{d t}=\underbrace{\rho_{j} s_{T}}_{\text {Supply }}-\underbrace{d_{N} N_{j}}_{\text {Turnover }}-\underbrace{\frac{V_{\text {tissue }}}{V_{\mathrm{LN}}} e^{-d_{D} \tau_{m}} \sum_{k=1}^{N}\left(k_{\mathrm{DC}} p_{j, k}\right) N_{j} M_{k}\left(t-\tau_{m}\right)}_{\text {Activation }},
$$

Change in naive killer $\mathrm{T}$ cell concentration:

$$
\frac{d N_{j}^{H}}{d t}=\underbrace{\rho_{j} s_{H}}_{\text {Supply }}-\underbrace{d_{N H} N_{j}^{H}}_{\text {Turnover }}-\underbrace{\frac{V_{\text {tissue }}}{V_{\mathrm{LN}}} e^{-d_{D} \tau_{m}} \sum_{k=1}^{N}\left(k_{\mathrm{DC}} p_{j, k}\right) N_{j}^{H} M_{k}\left(t-\tau_{m}\right)}_{\text {Activation }},
$$

Change in naive natural regulatory $\mathrm{T}$ cell concentration:

$$
\frac{d N_{R}}{d t}=\underbrace{s_{R}}_{\text {Supply }}-\underbrace{d_{N R} N_{R}}_{\text {Turnover }}-\underbrace{\frac{V_{\text {tissue }}}{V_{\mathrm{LN}}} e^{-d_{D} \tau_{m}} \sum_{k=1}^{N} \sum_{j=1}^{J}\left(k_{\mathrm{DC}} p_{j, k}\right) N_{R} M_{k}\left(t-\tau_{m}\right)}_{\text {Activation }},
$$

Change in effector killer $\mathrm{T}$ cell concentration:

$$
\begin{aligned}
& \frac{d T_{j}}{d t}=\overbrace{e^{-d_{N} \tau_{a}} \varphi(P) 2^{n_{T}} e^{-d_{D} \tau_{m}} \sum_{k=1}^{N}\left(k_{D C} p_{j, k}\right) N_{j}\left(t-\tau_{a}\right) M_{k}\left(t-\tau_{m}-\tau_{a}\right)}^{T \text { cell induction }} \\
& -\overbrace{d_{T} T_{j}}^{\text {Turnover }}-\overbrace{\mu R T_{j}}^{i \text { Treg suppression }}-\underbrace{\mu R_{N} T_{j}}_{n \text { Treg suppression }}+\underbrace{k_{G} G T_{j}}_{\text {Growth due to growth factors }},
\end{aligned}
$$

Change in effector helper $\mathrm{T}$ cell concentration:

$$
\frac{d H_{j}}{d t}=\overbrace{e^{-d_{N H} \tau_{a}} 2^{n_{H}} e^{-d_{D} \tau_{m}} \sum_{k=1}^{N}\left(k_{D C} p_{j, k}\right) \quad N_{j}^{H}\left(t-\tau_{a}\right) M_{k}\left(t-\tau_{m}-\tau_{a}\right)}^{\text {Tcellinduction }}
$$

Differentiation

$$
-\overbrace{k_{R} H_{j}}^{\text {intoiTregs }}-\overbrace{\mu R H_{j}}^{\text {iTreg supression }}-\underbrace{\mu R_{N} H_{j}}_{n \text { Treg supression }}+\underbrace{d_{H} H_{j}}_{\text {TurnoverGrowthduetogrowthfactors }} \underbrace{k_{G} G H_{j}},
$$

Change in natural regulatory $\mathrm{T}$ cell concentration:

$$
\frac{d R_{N}}{d t}=\underbrace{e^{-d_{N R} \tau_{a}} 2^{n_{R}} e^{-d_{D} \tau_{m}} \sum_{k=1}^{N} \sum_{j=1}^{J}\left(k_{\mathrm{DC}} p_{j, k}\right) N_{R}\left(t-\tau_{a}\right) M_{k}\left(t-\tau_{m}-\tau_{a}\right)}_{\text {nTreg induction }}-\underbrace{d_{R N} R_{N}}_{\text {Turnover }},
$$


Change in induced regulatory $\mathrm{T}$ cell concentration:

$$
\frac{d R}{d t}=\underbrace{k_{R} \sum_{j=1}^{J} H_{j}}_{\begin{array}{c}
\text { Differentiated } \\
\text { helper T cells }
\end{array}}-\underbrace{d_{R} R}_{\text {Turnover }},
$$

Change in concentration of positive growth factors:

$$
\begin{aligned}
\frac{d G}{d t}= & \underbrace{r_{1} \sum_{j=1}^{J} T_{j}}_{\text {Secretion }}+\underbrace{r_{2} \sum_{j=1}^{J} H_{j}}_{\text {Secretion by }}-\underbrace{k_{G} G \sum_{j=1}^{J}\left(T_{j}+H_{j}\right)}_{\text {Consumption }} \\
& \text { by CTLs helper T cells } \quad \text { by T cells } \\
& -\underbrace{d_{G} G}_{\text {Turnover }} .
\end{aligned}
$$

In Equation 9, naive CTLs in the lymph node of avidity $j$ are supplied at rate $\rho_{j} s_{T}$, where $\rho_{j}$ is the proportion supplied that have avidity $j$. These naive CTLs also exit the lymph node at rate $d_{N}$. The rate at which naive CTLs are activated by mature DCs that have migrated into the lymph node is

$$
\frac{V_{\text {tissue }}}{V_{\mathrm{LN}}} e^{-d_{\mathrm{D}} \tau_{m}} \sum_{k=1}^{N}\left(k_{\mathrm{DC}} p_{j, k}\right) N_{j} M_{k}\left(t-\tau_{m}\right) .
$$

Migration is modelled with a fixed delay of $\tau_{m}$, with $e^{-d_{D} \tau_{m}}$ being the proportion that survives migration. For intranodal injections, the value of $\tau_{m}$ is set to zero. The kinetic interaction rate between naive CTLs of avidity $j$ and mature DCs presenting $k$ vaccine-peptides is $k_{\mathrm{DC}}$ with $p_{j, k}$ being the probability of an interaction leading to successful activation. This means the net kinetic rate, $k_{\mathrm{DC}} p_{j, k}$, depends on both $\mathrm{T}$ cell avidity, $j$, and the number of pMHCs presented on a DC, $k$. Finally, the leading term $\frac{V_{\text {tissue }}}{V_{\text {LN }}}$ accounts for the volume change between the injection site and the lymph node. However, for intranodal injections, this ratio is set to one as there will be no change in volume. In Equation 10, which is similar to Equation 9, naive helper $\mathrm{T}$ cells of avidity $j$ are supplied at rate $\rho_{j} s_{H}$, decay at rate $d_{N H}$, and are activated at the net rate of

$$
\frac{V_{\text {tissue }}}{V_{\mathrm{LN}}} e^{-d_{D} \tau_{m}} \sum_{k=1}^{N}\left(k_{\mathrm{DC}} p_{j, k}\right) N_{j}^{H} M_{k}\left(t-\tau_{m}\right)
$$

In Equation 11, which is similar to Eqs 9 and 10, naive natural regulatory $\mathrm{T}$ cells (nTregs) are supplied at rate $s_{R}$, decay at rate $d_{N R}$, and are activated at the net rate of

$$
\frac{V_{\text {tissue }}}{V_{\mathrm{LN}}} e^{-d_{D} \tau_{m}} \sum_{k=1}^{N} \sum_{j=1}^{J}\left(k_{\mathrm{DC}} p_{j, k}\right) N_{R} M_{k}\left(t-\tau_{m}\right) .
$$

As we do not account nTregs of different avidities, we sum over the variable $j$.

Equations 12-16 describe interactions within the tumor site. In Equation 12, naive CTLs undergo $n_{T}$ divisions. The division program is modelled with a fixed delay of $\tau_{a}$, with $e^{d_{N} \tau_{a}}$ being the proportion that effectively activate and traffic to the tumor site. As a consequence, not all $\mathrm{T}$ cells that exit the lymph node arrive as effector $\mathrm{T}$ cells at the tumor site. These assumptions equate to a net supply rate of

$$
e^{-d_{N} \tau_{a}} 2^{n_{T}} k_{\mathrm{DC}} e^{-d_{D}} \tau_{m} \sum_{k=1}^{N} p_{j, k} N_{j}\left(t-\tau_{a}\right) M_{k}\left(t-\tau_{m}-\tau_{a}\right) .
$$

To account for T-cell hyporesponsiveness, we multiply Equation 20 by $\varphi(P)=\frac{\varphi_{0}}{\varphi_{0^{+}} \int_{0}^{t} P(s) d s}$. This ensures that antigen accumulation results in diminished effector CTL expansion. We also assume effector CTLs: decay at rate $d_{T}$; expand due to interactions with positive growth factors at rate $k_{G}$; and are suppressed by interactions with induced regulatory $\mathrm{T}$ cells at rate $\mu$. Given that induced regulatory $\mathrm{T}$ cells (iTregs) and effector nTregs have similar suppression rates $(63,64)$, we assume that nTregs suppress effector CTLs at an identical rate of $\mu$.

In Equation 13, naive helper $\mathrm{T}$ cells undergo $n_{H}$ divisions. Following a similar argument to that in Equation 12, the net supply rate of effector helper $\mathrm{T}$ cells is

$$
e^{-d_{N H} \tau_{a}} 2^{n_{H}} k_{\mathrm{DC}} e^{-d_{D} \tau_{m}} \sum_{k=1}^{N} p_{j, k} N_{j}\left(t-\tau_{a}\right) M_{k}\left(t-\tau_{m}-\tau_{a}\right) .
$$

These effector helper $\mathrm{T}$ cells differentiate into induced regulatory $\mathrm{T}$ cells at rate $k_{R}$; are suppressed by both iTregs and nTregs at rate $\mu$; decay at rate $d_{H}$; and expand due to interactions with positive growth factors at rate $k_{G}$.

In Equation 14, following a similar argument to that in Equation 12, effector nTregs enter the system at rate

$$
e^{-d_{N R} \tau_{a}} 2^{n_{R}} e^{-d_{D} \tau_{m}} \sum_{k=1}^{N} \sum_{j=1}^{J}\left(k_{D C} p_{j, k}\right) N_{R}\left(t-\tau_{a}\right) M_{k}\left(t-\tau_{m}-\tau_{a}\right),
$$

and decay at rate $d_{R N}$. In Equation 15, iTregs enter the system as differentiated effector helper $\mathrm{T}$ cells and decay at rate $d_{R}$. Finally, in Equation 16, effector CTLs and helper T cells secrete growth factors such as IL-2 at rates $r_{1}$ and $r_{2}$. These growth factors are assumed to decay at rate $d_{G}$.

\section{Cancer Cells}

To model the lysis of cancer cells and trogocytosis of cancer cell MHC by effector CTLs, we consider a population of cancer cells presenting $k$ vaccine-associated peptides, $C_{k}$, where $k$ varies from zero to $K$. The interactions between these cancer cells and effector CTLs are modelled with an ODE system:

$$
\begin{aligned}
\frac{d C_{0}}{d t}= & \gamma\left(1-C_{\text {total }} / \kappa\right)\left(C_{0}+C_{1}\right)-\alpha C_{0} \\
& +k_{T}\left(\sum_{j=1}^{N} T_{j}\right)\left(\sum_{m=1}^{K} C_{m} q_{m, m}\right),
\end{aligned}
$$




$$
\begin{aligned}
& \text { For } k=1, \cdots, K-1, \\
& \overbrace{\frac{d C_{0}}{d t}=\gamma\left(1-C_{\text {total }} / \kappa\right)\left(-C_{k}+2 C_{2 k}+C_{2 k-1}+C_{2 k+1}\right)}^{\text {Growth }}+\overbrace{\alpha\left(C_{k-1}-C_{k}\right)}^{p M H C \text { regeneration }} \\
& +\underbrace{k_{T}\left(\sum_{j=1}^{N} T_{j}\right)\left(\left(\sum_{m=k+1}^{K} C_{m} q_{m-k, m}\right)-C_{k}\left(1-q_{0, k}\right)\right)}_{\text {Trogocytosis }}-\underbrace{k_{T} \sum_{j=1}^{N} \lambda_{j, k} T_{j} C_{k}}_{\text {Lysis }} \\
& \frac{d C_{k}}{d t}=\gamma C_{k}\left(1-C_{\text {total }} / \kappa\right)+\alpha C_{K-1}-k_{T}\left(\sum_{j=1}^{N} T_{j}\right) \\
& \quad-k_{T} \sum_{j=1}^{N} \lambda_{j, k} T_{j} C_{k} .
\end{aligned}
$$

In Eqs 23-25, the total cancer population, $C_{\text {total }}=\Sigma_{k=0}^{K} C_{j}$, grows logistically at rate $\gamma$ and with carrying capacity $\kappa$. As a simplifying assumption, we assume that the number of surface peptides is halved after mitosis, resulting in a net compartmental growth rate of

$$
\gamma\left(1-\frac{C_{\text {total }}}{\kappa}\right)\left(-C_{k}+C_{2 k}+C_{2 k-1}+C_{2 k+1}\right),
$$

for the population of cancer cells presenting $k$ peptides, $C_{k}$. We also assume that surface peptides are regenerated at rate $\alpha$. To model trogocytosis-mediated MHC stripping, we assume that CTLs and cancer cells presenting $k$ peptides interact at rate $k_{T}$ and additionally assume the number of peptides stripped during this interaction is binomially distributed with probability $p_{T}$. For brevity we let $q_{m, n}=\left(\begin{array}{c}n \\ m\end{array}\right) p_{T}^{m}\left(1-p_{T}\right)^{n-m}$ denote the probability that a CTL will trogocytose $m$ MHC:peptides off a cancer cell presenting $n$ surface peptides. This allows us to describe the trogocytosis rate as

$$
k_{T}\left(\sum_{j=1}^{N} T_{j}\right)\left(\left(\Sigma_{m=k+1}^{K} C_{m} q_{m-k, m}\right)-C_{k}\left(1-q_{0, k}\right)\right) .
$$

Finally, to model lysis, we let $\lambda_{j, k}$ denote the lysis probability between a cancer cell presenting $k$ peptides and an effector CTL of avidity $j$ and assume that these interactions occur at rate $k_{T}$. This implies the net kinetic interaction rate depends on both $\mathrm{T}$ cell avidity and the amount of pMHC presented by a cancer cell. To model the lysis probability, we assume that the probability of lysis increases with cognate pMHCs but is also modulated by CTL avidity. This can be modelled by assuming a probability function of the form

$$
1-e^{-r_{j} k}
$$

where $r_{j}$ is an avidity-dependent rate parameter chosen so that the lysis probability at maximal levels of cognate pMHC expression, i.e., $\lambda_{j, k}$ varies linearly from $\omega_{1}$ for the lowest avidity CTL to $\omega_{J}$ for the highest avidity CTL.

\section{Functional Forms}

\section{Peptide Vaccine Injection Rate}

Here, we assume that the vaccine is injected systemically at a fixed dose, $u_{0}$, and at a regular interval of $\zeta$, which corresponds to the functional form

$$
u(t)=u_{0} \sum_{a=0}^{\infty} \delta(t-\zeta a)
$$

\section{Vaccine Adjuvant Injection Rate}

We assume that the vaccine adjuvant is injected at a clinicallyrelevant fixed dose of $5 \times 10^{5} \mathrm{ng} / \mathrm{mL}$ (19), and at a regular interval of $\eta$, corresponding to the functional form

$$
a(t)=\left(5 \times 10^{5} \mathrm{ng} / \mathrm{ml}\right) \times \sum_{n=0}^{\infty} \delta(t-n \eta) .
$$

\section{Peptide Uptake Rates}

We previously used ex vivo human data from (22) to estimate a mature DC uptake rate, $k_{P}$, of $3 \times 10^{-2}(\mathrm{k} / \mu \mathrm{L})^{-1} /$ day. It is generally understood that immature DCs, relative to mature DCs, have a greater uptake rate $(59,60)$. To estimate the uptake rate by iDCs, we use in vitro murine data from (23), who note that antigen internalization (as quantified by staining for the antibody YAe) in iDCs is 2.28 times greater than in mDCs. Thus, we assume that the uptake by iDCs, $k_{P i}$, is $2.28 \times k_{P}=6.84 \times 10^{-2}(\mathrm{k} / \mu \mathrm{L})^{-1} /$ day. To account for vaccine clearance by splenic macrophage, we first note the steady-state concentration of non-activated macrophages in mice is estimated to be $1.25 \times 10^{-1} \mathrm{k} / \mu \mathrm{L}$ (24). In (24), the authors also estimate the rate of phagocytosis by non-activated macrophages to be $25.2(\mathrm{k} / \mu \mathrm{L})^{-1} /$ day. Together, these correspond to a splenic macrophage associated vaccine clearance rate, $k_{P \phi}$ of $25.2(\mathrm{k} / \mu \mathrm{L})^{-1} /$ day $\times 0.125 \mathrm{k} / \mu \mathrm{L}=3.1875 /$ day.

\section{Activation Probability}

The probability of a mature DC presenting $k$ vaccine-associated pMHCs activating a naive T cell of avidity $j, p_{j, k}$, is modelled with a switch:

$$
p_{j, k}= \begin{cases}1, & \text { if }\left|\frac{j-1}{J-1}-\left(1-\frac{k-1}{N_{c}-1}\right)\right| \leq v \text { and } k<N_{c} \\ 1, & \text { if } j=1 \quad \text { and } k \geq N_{c} \\ 0, & \text { otherwise. }\end{cases}
$$

Here, $1 /\left(N_{c}-1\right)$ and $1 /(J-1)$ map $j$ and $k$ from their respective domains to $[0,1]$. The dimensionless parameter $v=$ 0.05 determines how sensitive our switching function is to pMHC expression. This characterization ensures that and high pMHC levels on DCs stimulate both high- and low-avidity CTLs (20, 65-69) and by contrast, low pMHC expression stimulates mostly high-avidity CTLs $(10,70-72)$. To reflect this, we assumed that beyond a critical number of pMHCs, $N_{c}$, only low-avidity CTLs were stimulated. We set $N_{c}=N / 2=350$, implying that DCs must have a surface antigen density below $50 \%$ to stimulate high-avidity CTLs. 


\section{Initial Conditions}

We assume that the vaccine is first administered at $t=0$, i.e., $P(0)=$ $u_{0}$, where $u_{0}$ is the vaccine dose. Our model assumes a large number of immature DCs preexist at the injection site. In (73), the total DC population at steady-state conditions in the dermis is estimated to be approximately $23.4 \mathrm{k} / \mu \mathrm{L}$. Around $92.74 \%$ of this population is expected to immature (74), equating to an initial iDC concentration at the injection site of $21.7 \mathrm{k} / \mu \mathrm{L}$. Similarly, $7.26 \%$ of the total DC population is expected to be mature (74), equating to a total $\mathrm{mDC}$ concentration of $1.7 \mathrm{k} / \mu \mathrm{L}$. For intravenous injections, we use a total DC concentration of $25 \mathrm{DCs} / \mu \mathrm{L}$ (75), and assume that $90 \%$ of this population is immature, equating to an iDC concentration of $22.5 \mathrm{DCs} / \mu \mathrm{L}$ and total $\mathrm{mDC}$ concentration of $2.5 \mathrm{DCs} / \mu \mathrm{L}$. Finally, for intranodal injections, we use a pre-existing LN iDC count of 25,190 cells, and an mDC count of 32,920 cells (26), which for a control volume of $V_{\mathrm{LN}}$, equates to an iDC concentration of $5.9976 \mathrm{k} / \mu \mathrm{L}$, and a total $\mathrm{mDC}$ concentration of $7.8381 \mathrm{k} / \mu \mathrm{L}$. Moreover, we assume that within this mature DC population, pMHCs are normally distributed with mean $\mu=100$ and variance $\sigma^{2}=25$ (76). As a simplifying assumption, we assume the initial concentration of semi-mature/tolerizing DCs is zero.

To model the scarcity of high-avidity naive T cells, we assume that their availability decreases exponentially. Specifically, we assume $N_{j}(0)=\rho_{j} N(0)$ and $N_{j}^{H}(0)=\rho_{j} N^{H}(0)$, where $\rho_{j}=a e^{-b j}$. Here, the model parameters $a$ and $b$ are chosen so that $\Sigma_{j=1}^{J} \rho_{j}=1$ and $\rho_{1} / \rho_{J}$, i.e., the ratio low-avidity to high-avidity $\mathrm{T}$ cells, equates to the model parameter $R_{\mathrm{LH}}$. In our simulations, we set $R_{\mathrm{LH}}$ to 100 , which means that for one high-avidity $\mathrm{T}$ cell there are 100 low-avidity $\mathrm{T}$ cells. Moreover, naive natural regulatory $\mathrm{T}$ cells, $N_{R}$, make up roughly $5 \%$ of the naive helper $\mathrm{T}$ cell population (39), thus, we set $N_{R}(0)=0.05 \times N^{H}(0)$.

Prior to vaccination, tumor-specific effector $\mathrm{T}$ cells exist, albeit at low concentrations (approximately $0.12 \%$ of the total CD8+ count) (77). Assuming a total CD8+ count of 600 cells/ $\mu \mathrm{L}$ (78), this equates to an initial tumor-specific effector CTL concentration of 0.72 cells $/ \mu \mathrm{L}$. To estimate the initial tumor-specific effector helper $\mathrm{T}$ cell concentration, we assume a comparable percentage (i.e., $0.12 \%$ ) also exists before vaccination. Using a circulating helper T cell concentration of $10^{3}$ cells/ $\mu \mathrm{L}$ (79), this corresponds to an initial tumor-specific effector helper $\mathrm{T}$ cell concentration of 1.2 cells/ $\mu \mathrm{L}$. Moreover, approximately $1.5 \%$ of this helper T cell pool expresses the natural regulatory $\mathrm{T}$ cell phenotype (39), which equates to an initial effector natural regulatory $\mathrm{T}$ cell concentration of $R_{N}(0)=1.8 \times 10^{-2}$ cells $/ \mu \mathrm{L}$. As a simplification, we assume that initially there are no induced regulatory $\mathrm{T}$ cells, i.e., $R(0)=0$, and that the concentration of growth factor is zero, i.e., $G(0)=0$. Finally, to account for the scarcity of high-avidity $\mathrm{T}$ cells, we multiply the concentrations of effector CTLs and effector helper T cells by $\rho_{j}$ (defined in the above paragraph). Mathematically, $T_{j}$ $(0)=\rho_{j} \times 0.72$ cells $/ \mu \mathrm{L}$ and $H_{j}(0)=\rho_{j} \times 1.2$ cells $/ \mu \mathrm{L}$. In other words, initially, for every high-avidity tumor-specific effector $\mathrm{T}$ cell, there are 100 low-avidity tumor-specific effector T cells.

Finally, we assume that the total cancer cell concentration is $C_{\text {init }}$, with cognate pMHC being normally distributed with mean $\mu=148$ and variance $\sigma^{2}=49$. Mathematically, if $f_{k}=\frac{1}{\sigma \sqrt{2 \pi}} \exp \left(-\frac{(k-\mu)^{2}}{2 \sigma^{2}}\right)$, then $C_{k}(0)=C_{\text {init }} \times \frac{f_{k}}{\Sigma_{k=1}^{K} f_{k}}$.

\section{Sensitivity Analysis}

To understand how DC maturation status affects parameter sensitivity, we conduct sensitivity analysis on our modified model. We account for non-linear interactions between parameters by varying all parameters simultaneously using Latin hypercube sampling $(n=250)$ over the ranges shown in Table 2, and measure sensitivity by calculating Spearman's rank correlation coefficient (SRCC), $\rho$, for each parameter against the fold decrease. These simulations use a peptide vaccine dosage of $7 \times 10^{5} \mathrm{ng}$ fortnightly, with an iDC dosage of $10^{6}$ cells/ $\mu \mathrm{L}$ injected at the same time as the peptide vaccine. Table 2 shows SRCC $\rho$ for each parameter.

In our previous model, a sensitivity analysis identified antigen presentation by DCs as a key variable for the beneficial

TABLE 2 | Spearman's rank correlation coefficient between modified model parameters and fold decreases of simulations when varied simultaneously.

\begin{tabular}{|c|c|c|c|}
\hline Parameter & Description & Range & SRCC \\
\hline$d_{p}$ & Peptide decay rate & $\pm 50 \%$ & 0.0575 \\
\hline$k_{p}$ & Mature DC uptake rate & $\pm 50 \%$ & 0.0283 \\
\hline$k_{P i}$ & Immature DC uptake rate & $\pm 50 \%$ & -0.0825 \\
\hline$k_{P \phi}$ & $\begin{array}{l}\text { Clearance rate due to splenic } \\
\text { macrophages }\end{array}$ & $\pm 50 \%$ & -0.0342 \\
\hline$k_{D}$ & Mature DC presentation rate & $\pm 50 \%$ & -0.0274 \\
\hline$\chi$ & $\begin{array}{l}\text { Concentration of non-vaccine-associated } \\
\text { proteins }\end{array}$ & $\pm 50 \%$ & -0.0530 \\
\hline$\delta_{D}$ & Immature DC decay rate & $\pm 50 \%$ & 0.0198 \\
\hline$d_{A}$ & Adjuvant washout rate & $\pm 50 \%$ & 0.1015 \\
\hline$d_{D}$ & Mature DC decay rate & $\pm 50 \%$ & 0.0989 \\
\hline$k_{S}$ & $\begin{array}{l}\text { Semi-matured/tolerized DC maturation } \\
\text { rate }\end{array}$ & $\pm 50 \%$ & 0.0505 \\
\hline$d_{m}$ & pMHC degradation rate & $\pm 50 \%$ & -0.0322 \\
\hline$d_{N}$ & Naive CTL egress rate & $\pm 50 \%$ & -0.1761 \\
\hline$d_{N H}$ & Naive helper $T$ cell egress rate & $\pm 50 \%$ & -0.0490 \\
\hline$d_{N R}$ & Naive nTreg turnover rate & $\pm 50 \%$ & -0.0285 \\
\hline$\tau_{m}$ & DC migration time & $\pm 50 \%$ & 0.0717 \\
\hline$k_{D C}$ & Naive CTL-DC interaction rate & $\pm 50 \%$ & -0.1214 \\
\hline$V_{\text {tissue }}$ & Volume of tissue site & $\pm 50 \%$ & 0.0427 \\
\hline$V_{\mathrm{LN}}$ & Volume of lymph node & $\pm 50 \%$ & -0.0591 \\
\hline$R_{\mathrm{LH}}$ & Ratio of low-high avidity naive CTLs & $10-500$ & -0.0630 \\
\hline$\tau_{a}$ & T cell division time & $\pm 50 \%$ & 0.0536 \\
\hline$\Phi_{0}$ & Antigen saturation constant & $\pm 50 \%$ & -0.0239 \\
\hline$n_{T}$ & Number of CTL divisions & $10-20$ & 0.4981 \\
\hline$n_{H}$ & Number of helper T cell divisions & $4-10$ & -0.0036 \\
\hline$n_{R}$ & Number of nTreg divisions & $\pm 50 \%$ & -0.2096 \\
\hline$d_{R}$ & iTreg decay rate & $\pm 50 \%$ & 0.0907 \\
\hline$d_{R N}$ & Effector nTreg decay rate & $\pm 50 \%$ & -0.1181 \\
\hline$d_{T}$ & Effector CTL decay rate & $\pm 50 \%$ & 0.0497 \\
\hline$\mu$ & CTL-Treg interaction rate & $\pm 50 \%$ & -0.2410 \\
\hline$k_{G}$ & T cell-growth factor interaction rate & $\pm 50 \%$ & -0.0841 \\
\hline$k_{R}$ & iTreg differentiation rate & $\pm 50 \%$ & 0.0951 \\
\hline$d_{H}$ & Effector helper $T$ cell decay rate & $\pm 50 \%$ & -0.0119 \\
\hline$r_{1}$ & Secretion rate of growth signal by CTLs & $\pm 50 \%$ & 0.0557 \\
\hline$r_{2}$ & $\begin{array}{l}\text { Secretion rate of growth signal by helper } \\
\mathrm{T} \text { cells }\end{array}$ & $\pm 50 \%$ & 0.0508 \\
\hline$d_{G}$ & Growth factor decay rate & $\pm 50 \%$ & 0.0774 \\
\hline$\gamma$ & Growth rate of melanomas & $\begin{array}{c}3 \times 10^{-3} \text { to } \\
8.7 \times 10^{-2} / \text { day }\end{array}$ & -0.7318 \\
\hline$\kappa$ & Carrying capacity of melanomas & $\begin{array}{l}48.7 \text { to } 2360 \\
k / \mu L\end{array}$ & 0.0260 \\
\hline$\alpha$ & pMHC regeneration rate & $\pm 50 \%$ & 0.0925 \\
\hline$k_{T}$ & Tumor-CTL interaction rate & $\pm 50 \%$ & 0.0998 \\
\hline$p_{T}$ & Probability of trogocytosis & $\pm 50 \%$ & -0.1336 \\
\hline$\omega_{1}$ & Lysis likelihood for lowest avidity $(j=1)$ CTL & $\pm 50 \%$ & 0.0588 \\
\hline
\end{tabular}


therapeutic value of vaccines. Here, we amend our model with the induction of immature DCs, resulting in supraphysiological levels of DCs. The resulting scale difference reduces the power of DC-associated parameters. Additionally, the model is now sensitive to the tumor growth rate, $\gamma$, suggesting that characteristics such as proliferative and apoptotic cell rates may affect the clinical response to the therapeutic vaccine.

\section{RESULTS}

\section{Modified Mathematical Model}

We previously found that the rate of antigen presentation by DCs determined the therapeutic value of an anti-tumor CTL response (16). Here, we hypothesize that inducing high levels of immature DCs would preferentially stimulate naive high-avidity CTLs by increasing the total concentration of mature DCs while lowering the average antigen density per DC. To test this proposed approach, we change Equation 2 in our original model (see Materials and Methods) to include a source term, $v(t)$, which describes the elicitation of immature DCs, either by injection of ex vivo derived DCs or by recruitment of DC progenitors from the bone marrow via cytokine stimulation:

$$
\frac{d I}{d t}=s_{D}+v(t)-\delta_{D} I-k_{D} \frac{P}{\chi+P} I .
$$

As a simplifying assumption, we assume that induced immature DCs (iDCs) are given at a fixed dose $v_{0}$, and at dosing intervals of $\xi$ hours after the injection of the peptide vaccine, which leads to the functional form:

$$
v(t)=v_{0} \sum_{a=0}^{\infty} \delta\left(t-\xi_{a}\right) .
$$

Figure 1 uses a block diagram to depict the key interactions of our model.

\section{Increased immature DC levels yields lower peptide:MHC levels and tumor cell reduction}

In our example, we assume our tumor is a melanoma and assume that our vaccine either targets either neo-antigen peptides or classical antigens such as MART1. Initially, we simulate the DC context of the vaccine while leaving the peptide dosage fixed at the previously optimized value of $100 \mathrm{ng}$ daily. Using this low peptide dosing, we effectively fix the pMHC levels on DCs to be low. To assess the robustness of our modified model, we next simulated iDC doses ranging from $10^{3}$ cells $/ \mu \mathrm{L}$ to $10^{12}$ cells $/ \mu \mathrm{L}$, with dosing intervals that range from 0 to 24 hours after a peptide injection. For these simulations, we assume that our vaccine adjuvant is delivered at a dose of $10^{5} \mathrm{ng}$ simultaneously with the peptide vaccine.

A global sweep of iDC dosages within these ranges identified multiple iDC induction magnitudes as being optimal, i.e., inducing a $>90 \%$ decrease in tumor burden (Figure 2A). For example, an iDC induction magnitude of $10^{6} \mathrm{iDCs} / \mu \mathrm{L}$ given at the same time as the peptide vaccine, induced a $97 \%$ decrease in tumor burden.
Importantly, the substantial reduction in tumor concentration we observed is neither dose dependent nor time dependent within our parameters, with a wide range of iDC concentrations and dosing intervals achieving a high degree of tumor reduction. Indeed, for iDC doses between $10^{2}$ to $10^{7} \mathrm{k} / \mu \mathrm{L}$, the percentage decrease in tumor concentration varies minimally from the local optimum regardless of the dosing interval used. We thus find that the temporal robustness of this system centered around iDC induction and high-avidity $\mathrm{T}$ cell induction potentially allows for the possibility of introducing other combinatorial therapeutic strategies that may synergize with vaccine strategies, including checkpoint blockade and inducers of immunogenic cell death.

Our initial results demonstrated that increased iDC levels, rather than increased mDC levels, favor robust tumor clearing. We next set to determine if similar results could be recapitulated with clinically relevant vaccine dosages, rather than the $100 \mathrm{ng}$ daily peptide dose identified by our previous model. We first compared pMHC levels in three therapeutic variations: peptide with either no DCs, induction of iDCs, or induction of mDCs with around $6 \times 10^{6}$ DCs (which, for a control volume of $V_{\mathrm{LN}}=4.2 \mu \mathrm{L}$, equates to a concentration of $1.43 \times 10^{3} \mathrm{k} / \mu \mathrm{L}$ ), a dosing concentration similar to previously used in a clinical setting and within optimal concentrations found in our global sweep above (80). We assume that within this population of ex vivo matured DCs (mDCs), pMHCs are normally distributed with mean $\mu=100$ and variance $\sigma^{2}=25$ (76). Additionally, we compare peptide dosing concentrations for both an ideal $100 \mathrm{ng}$ daily and a clinically relevant $7 \times 10^{5}$ ng every 2 weeks (20). Our model shows that at both peptide doses, induction of iDCs results in increased pMHClow mature DCs as compared to no DC or $\mathrm{mDC}$ conditions (Figure 2B). This reduced antigen density in the context of the same peptide injection concentrations is due to the significantly increased numbers of $\mathrm{mDCs}$ generated by inducing iDCs (Figure 2B). These increased numbers are due to the longer half-life of iDCs as compared to mDCs, which are thought to rapidly decay upon maturation. As a result, the same peptide concentration dispensed over a larger number of DCs results in lower $\mathrm{pMHC}$ levels per DC.

\section{Immature DCs Promote High-Avidity T Cells and Tumor Clearance in Clinically Relevant Dosing Schemes}

Previously, we showed lower levels of pMHC competitively favor the expansion of high-avidity $\mathrm{T}$ cells rather than low-avidity $\mathrm{T}$ cells (16). As expected, we find that at both peptide dosing schemes induction of iDCs significantly favors the generation of high-avidity $\mathrm{T}$ cells compared to $\mathrm{mDCs}$ (Figure $\mathbf{3 A}$ ). The optimal low dose of $100 \mathrm{ng}$ daily of peptide significantly favors the development of high-avidity $\mathrm{T}$ cells, but even with the clinically relevant dosing of $7 \times 10^{5}$ ng every 2 weeks, the induction of iDCs significantly shifts the balance of $\mathrm{T}$ cell composition to favor high-avidity $\mathrm{T}$ cells. This highlights that while traditional $\mathrm{mDC}$ or peptide-only vaccination strategies do increase T-cell induction, they do so at the expense of highavidity $\mathrm{T}$ cells. In reflection of increased expansion of highavidity $\mathrm{T}$ cells, our simulations further demonstrate that iDC induction results in improved cancer cell lysis (Figure 3B). 


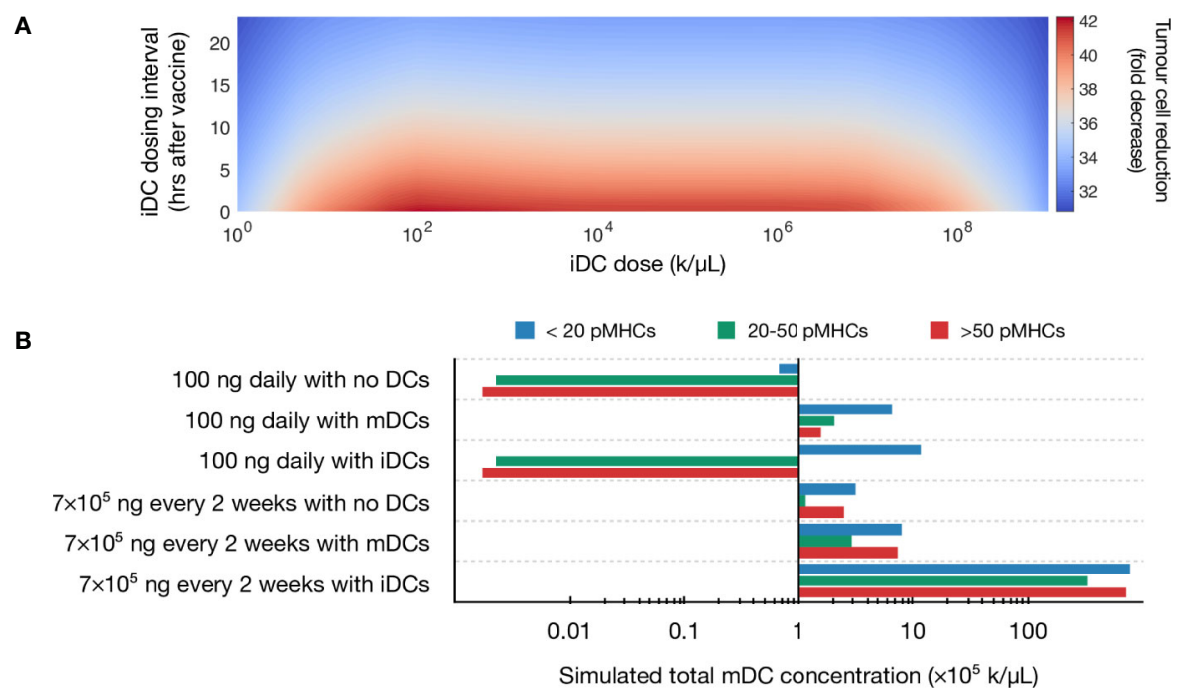

FIGURE 2 | Simulated induction of iDCs favors tumor reduction. (A) Heatmap depicts predicted tumor cell reduction (fold change) for different iDC dosages when given with $100 \mathrm{ng}$ of peptide daily. Here, the unit ' $\mathrm{k}$ ' denotes $10^{3}$ cells. (B) Stacked bar chart visualizing the predicted distribution of antigen on mature DCs for various vaccine protocols.

Finally, we compared vaccine responses in three different delivery routes: intramuscular, intravenous, and intranodal. For intramuscular case, at most, only $4 \%$ of DCs are expected to arrive at the LN (81). To model this, we multiply the source terms (described by Eqs 17-20) by 4\%. To model intravenous delivery, we modify our initial conditions so that DCs in our model are characterized by blood DC data (75). Finally, to model intranodal delivery, we assume there is no migratory delay between the injection site and the LN (i.e., $\tau_{m}=0$ ), and that there is no volume change between DC compartment and the LN compartment. Our simulations suggest that in the context of avidity-selection and tumor clearance (see Figure 3C), DC vaccination route is a critical consideration for maximizing vaccine efficiency. iDCs intranodal injections followed by intravenous injection were both preferable over intradermal DC injections. This data highlights the importance of high iDC cell numbers accumulating in the LN in our vaccination model.

\section{DISCUSSION}

Cancer immunotherapy is now a routine means of successfully treating tumors of various types in the clinic. However, improved immunotherapies to benefit greater numbers of patients with increased durability are still needed. Despite its tremendous successes, ICB therapy only benefits less than the majority of patients treated (82-84) and presents significant risks for adverse side-effects (85-87). Therapeutic peptide vaccines can robustly induce a tumor-specific CTL response with limited side effects due to induction of an antigen-specific immune response rather than broad immune activation (20). Preferential development of high avidity anti-tumor CTLs enables enhanced tumor cell killing $(9,18)$. Previously, we showed that vaccine dosages could be optimized to preferentially elicit high-avidity CTLs, unlike standard dosages that elicit low-avidity CTLs (16). In that study, we showed that the efficacy of a dosage-optimized approach depended on DC-related parameters, which motivated us to explore how we could harness immature DCs to boost anti-tumor activity.

High peptide antigen doses have been shown experimentally to result in low avidity and $\mathrm{T}$ cell responses $(88,89)$. However dosing timing strategy has been shown to have a significant effect on the average avidity of a $\mathrm{T}$ cell population $(90,91)$. Other work has shown that modulation of antigen presenting cells is a key component of the induction of high avidity $\mathrm{T}$ cells (92). We hypothesized that increasing the magnitude of iDCs given with a dosage-optimized peptide vaccine may enhance CTL responses. It is important to stress that this approach is conceptually different from traditional DC vaccines in which ex vivo matured DCs are injected $(3,17)$. To assess this approach, we extended our previous model to account for a hypothetical induction of iDCs. We show that induction of iDCs, and not mDCs, can significantly reduce tumor burden, improving upon the performance of a peptide vaccine. A key assumption of our model is that iDCs will have a longer half-life and inducing iDCs will result in a larger overall pool of DCs as compared to the injection of mDCs, which are known to have a shorter half-life (62). Our simulations show that these effects are tied to the increased half-life of iDCs and therefore increased DC levels in general, which results in a lower average antigen density per DC. As such, induction of iDCs favors the preferential stimulation of high-avidity CTLs and tumor cell clearance. In support of our findings, increased circulating DC levels have been associated with increased survival in certain malignancies (93-95). Further experimental or clinical evidence of the relationship between circulating DC levels and vaccination efficacy is needed. 

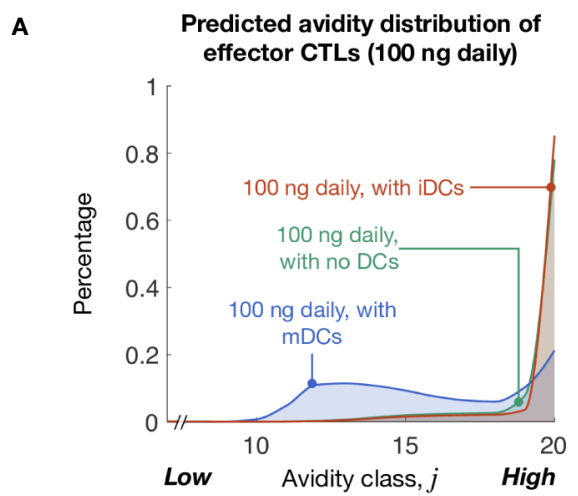

B
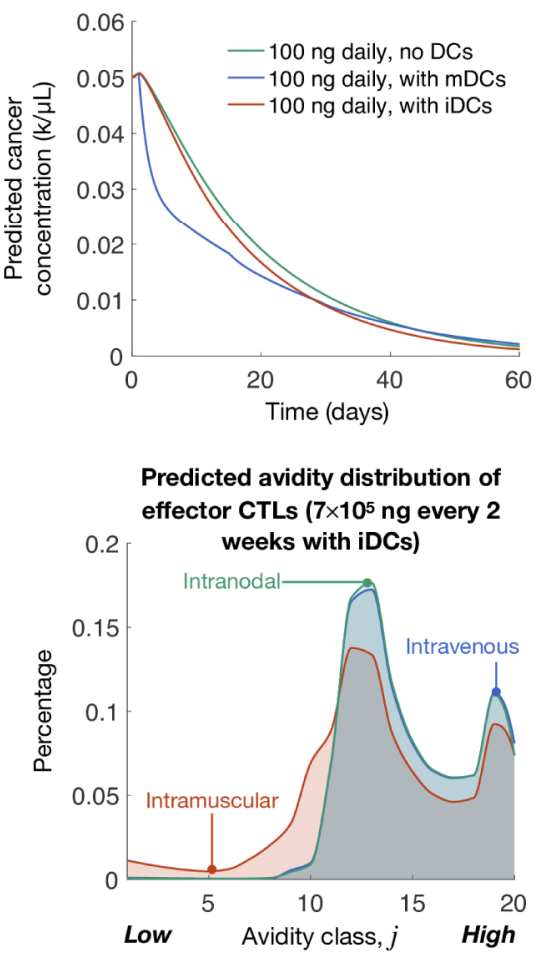
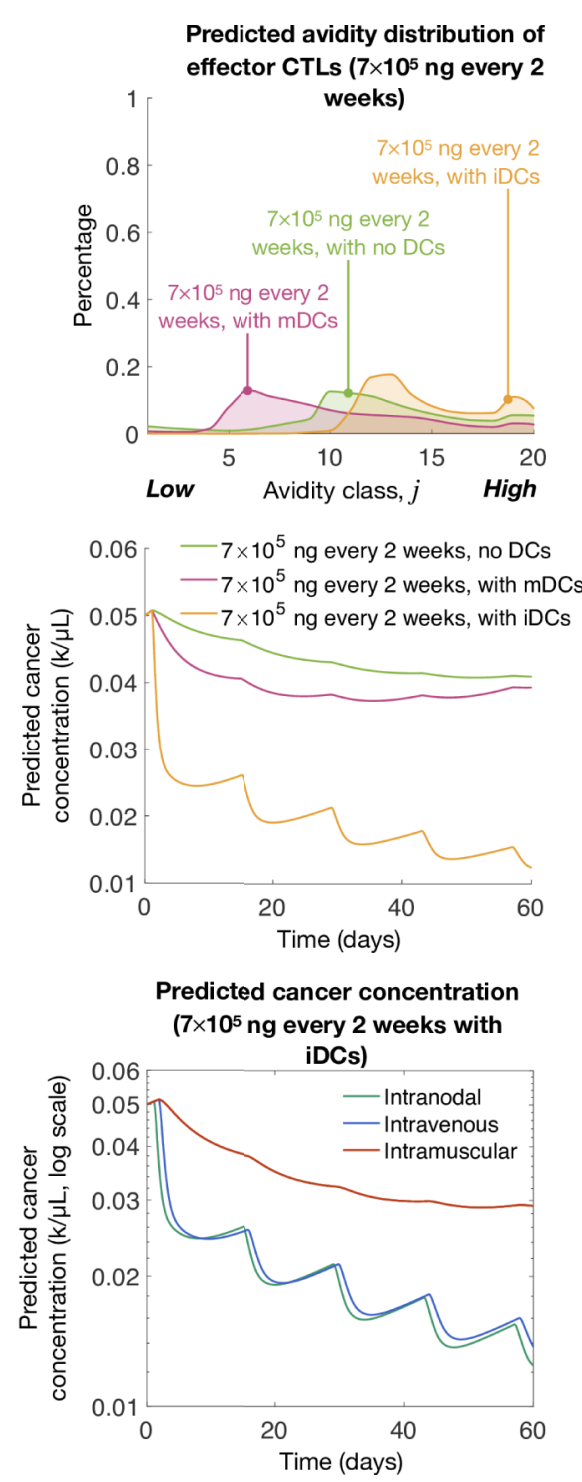

FIGURE 3 | Simulated induction of iDCs at clinically relevant vaccination doses yields significant tumor cell clearance. (A) Simulated avidity distribution of effector T cells for various vaccine protocols. (B) Simulated cancer concentrations over time for various vaccine protocols. (C) Simulated avidity distribution of effector T cells and tumor cell reduction (fold change) for different delivery routes. The unit ' $k$ ' denotes $10^{3}$ cells.

Early cancer vaccines targeting over-expressed CAAs such as MART-1, MAGE, NYE-ESO-1, HER2, and MUC-1 demonstrated mediocre clinical results. Evidence suggests that the $\mathrm{T}$ cell repertoire capable of responding to these antigens are primarily composed of low-avidity $\mathrm{T}$ cells due to central tolerance of $\mathrm{T}$ cells specific for selfantigens (96). Recently, there has been renewed interest in cancer vaccines due to promising results for those targeting neoantigens (97-100). Additionally, encouraging preliminary clinical results have recently been observed in therapeutic approaches combining DC vaccines with checkpoint blockade (101). Our findings suggest that inducing increased iDC levels would benefit vaccines targeting either over-expressed CAAs or neoantigens, as the expansion of high-avidity CTLs would favor clinical responses in both scenarios.
Initial DC vaccines, such as Sipuleucel-T, were major milestones for immunotherapy-based treatments of cancer and demonstrated modest, but meaningful, clinical results (102). While DC vaccines have not achieved widespread therapeutic success, it is unclear if this is a result of targeting TAAs, the influence of previously unknown immunosuppression mechanisms in the tumor microenvironment, or difficult in manufacturing cell products (103). While traditional DC vaccines have been based on ex vivo antigen loading and maturation of autologous DCs, our model finds that injecting iDCs results in a maximal anti-tumor response. We find that intranodal injection, as compared to intradermal or intravenous injection, results in the most $\mathrm{T}$ cell activation as it ensures high 
numbers of DCs are loaded with low pMHC levels. Although repeated intranodal injection of iDCs is not an ideal clinical scenario, it highlights the importance of recent bioengineering efforts to localize tumor antigen vaccination to lymph node sites (104). However, intravenous injection of iDCs did result in substantial tumor burden reduction. We suggest that other alternatives to iDC generation and injection, such as mobilization of bone marrow DC precursors, is an attractive possibility for future consideration in tumor vaccine design. Treatments with cytokines such as Fms-like tyrosine kinase 3 ligand (Flt3L) has demonstrated efficacy in increasing levels of circulating DCs (105-107). Our model suggests that elevated levels of iDCs, rather than mDCs, favors a longer half-life of the circulating DC compartment and results in lower average pMHC levels that would then favor high-avidity $\mathrm{T}$ cell generation. Therefore, induction of iDCs by any of several means followed by peptide vaccination and adjuvant for in vivo DC maturation would favor tumor clearance. While our model simplistically accounts for adjuvant as a necessary requirement for DC maturation and activation of $\mathrm{T}$ cells, we acknowledge that different adjuvant choices may have highly variable effects on DC activation and downstream T cell differentiation $(108,109)$.

Our work addresses an important and less appreciated element of cancer vaccines - how vaccine design and administration can select for and enhance the proliferation of high-avidity CTLs. However, there remain many barriers to efficacy with a combination strategy that our model does not consider. For example, we do not account for potential intra-tumoral heterogeneity of antigen expression, factors influencing CTL trafficking to tumor sites, or a multitude of potential immune suppression mechanisms found within tumor microenvironments. Additionally, in modelling the $\mathrm{T}$ cell activation we do not explicitly model TCR signaling. Future work will involve incorporating

\section{REFERENCES}

1. Zappasodi R, Merghoub T, Wolchok JD. Emerging Concepts for Immune Checkpoint Blockade-Based Combination Therapies. Cancer Cell (2018) 33 (4):581-98. doi: 10.1016/j.ccell.2018.03.005

2. Trujillo JA, Sweis RF, Bao R, Luke JJ. T Cell-Inflamed versus Non-T CellInflamed Tumors: A Conceptual Framework for Cancer Immunotherapy Drug Development and Combination Therapy Selection. Cancer Immunol Res (2018) 6(9):990-1000. doi: 10.1158/2326-6066.CIR-18-0277

3. Saxena M, Bhardwaj N. Re-Emergence of Dendritic Cell Vaccines for Cancer Treatment. Trends Cancer (2018) 4(2):119-37. doi: 10.1016/ j.trecan.2017.12.007

4. Jandus C, Usatorre AM, Vigano S, Zhang L, Romero P. The Vast Universe of T Cell Diversity: Subsets of Memory Cells and Their Differentiation. Methods Mol Biol (2017) 1514:1-17. doi: 10.1007/978-1-4939-6548-9_1

5. Abbas AK, Lichtman AHH, Pillai S. Cellular and Molecular Immunology. Philadelphia, Pennsylvania, USA: Elsevier Health Sciences (2014).

6. Slingluff CL. The present and future of peptide vaccines for cancer: single or multiple, long or short, alone or in combination? Cancer J (2011) 17(5):343-50. doi: 10.1097/PPO.0b013e318233e5b2

7. Lollini PL, Cavallo F, Nanni P, Forni G. Vaccines for tumour prevention. Nat Rev Cancer (2006) 6(3):204-16. doi: 10.1038/nrc1815

8. Mougel A, Terme M, Tanchot C. Therapeutic Cancer Vaccine and Combinations With Antiangiogenic Therapies and Immune Checkpoint Blockade. Front Immunol (2019) 10:467. doi: 10.3389/fimmu.2019.00467 existing validated models of TCR signaling (110), and calibrating these models to avidity data from $(111,112)$. Defining the minimum complexity of the immune system is challenging, and the model used in this study does not, nor does it aim to account for all known immune interactions.

The mathematical model presented here proposes that increasing the magnitude of iDCs with an optimized peptide vaccine may improve tumor clearance. The model highlights the relative importance of antigen loads on DCs, which facilitate the selective expansion of high-avidity CTLs. While pre-clinical experimental validation of our findings are necessary, our model suggests previously unappreciated aspects of vaccine design that may be necessary for the development of effective cancer treatments.

\section{DATA AVAILABILITY STATEMENT}

All datasets presented in this study are included in the article.

\section{AUTHOR CONTRIBUTIONS}

AK performed the simulations and formal analysis. AK and CE wrote the first draft of the manuscript. All authors contributed to the article and approved the submitted version.

\section{FUNDING}

This work was supported by an Australian Government Research Training Program Scholarship; an Australian Research Council Discovery Project [DP180101512]; and by the US Department of Defense Breast Cancer Research Program [W81XWH-11-1-0548].

9. Stuge TB, Holmes SP, Saharan S, Tuettenberg A, Roederer M, Weber JS, et al. Diversity and recognition efficiency of T cell responses to cancer. PloS Med (2004) 1(2):e28. doi: 10.1371/journal.pmed.0010028

10. McMahan RH, Slansky JE. Mobilizing the low-avidity T cell repertoire to kill tumors. Semin Cancer Biol (2007) 17(4):317-29. doi: 10.1016/j.semcancer. 2007.06.006

11. $\mathrm{Hu} \mathrm{Z}$, Ott PA, Wu CJ. Towards personalized, tumour-specific, therapeutic vaccines for cancer. Nat Rev Immunol (2018) 18(3):168-82. doi: 10.1038/ nri.2017.131

12. Schumacher TN, Schreiber RD. Neoantigens in cancer immunotherapy. Science. (2015) 348(6230):69-74. doi: 10.1126/science.aaa4971

13. Pan RY, Chung WH, Chu MT, Chen SJ, Chen HC, Zheng L, et al. Recent Development and Clinical Application of Cancer Vaccine: Targeting Neoantigens. J Immunol Res (2018) 2018:4325874. doi: 10.1155/2018/4325874

14. Speiser DE, Baumgaertner P, Voelter V, Devevre E, Barbey C, Rufer N, et al. Unmodified self antigen triggers human CD8 T cells with stronger tumor reactivity than altered antigen. Proc Natl Acad Sci USA (2008) 105(10):384954. doi: 10.1073/pnas.0800080105

15. Kittlesen DJ, Thompson LW, Gulden PH, Skipper JC, Colella TA, Shabanowitz J, et al. Human melanoma patients recognize an HLA-A1-restricted CTL epitope from tyrosinase containing two cysteine residues: implications for tumor vaccine development. J Immunol (1998) 160(5):2099-106.

16. Kumbhari A, Kim PS, Lee PP. Optimisation of anti-cancer peptide vaccines to preferentially elicit high-avidity T cells. J Theor Biol (2019) 486:110067. doi: $10.1016 /$ j.jtbi.2019.110067 
17. Perez CR, De Palma M. Engineering dendritic cell vaccines to improve cancer immunotherapy. Nat Commun (2019) 10(1):5408. doi: 10.1038/ s41467-019-13368-y

18. Chung B, Stuge TB, Murad JP, Beilhack G, Andersen E, Armstrong BD, et al. Antigen-specific inhibition of high-avidity $\mathrm{T}$ cell target lysis by low-avidity $\mathrm{T}$ cells via trogocytosis. Cell Rep (2014) 8(3):871-82. doi: 10.1016/ j.celrep.2014.06.052

19. Hailemichael Y, Dai Z, Jaffarzad N, Ye Y, Medina MA, Huang X-F, et al. Persistent antigen at vaccination sites induces tumor-specific CD8+ T cell sequestration, dysfunction and deletion. Nat Med (2013) 19(4):465-72. doi: 10.1038/nm.3105

20. Rezvani K, Yong ASM, Mielke S, Jafarpour B, Savani BN, Le RQ, et al. Repeated PR1 and WT1 peptide vaccination in Montanide-adjuvant fails to induce sustained high-avidity, epitope-specific CD8+ T cells in myeloid malignancies. Haematologica (2011) 96(3):432-40. doi: 10.3324/haematol. 2010.031674

21. Harndahl M, Rasmussen M, Roder G, Dalgaard Pedersen I, Sorensen M, Nielsen M, et al. Peptide-MHC class I stability is a better predictor than peptide affinity of CTL immunogenicity. Eur J Immunol (2012) 42(6):140516. doi: 10.1002/eji.201141774

22. Sallusto F, Cella M, Danieli C, Lanzavecchia A. Dendritic cells use macropinocytosis and the mannose receptor to concentrate macromolecules in the major histocompatibility complex class II compartment: downregulation by cytokines and bacterial products. J Exp Med (1995) 182(2):389-400. doi: 10.1084/jem.182.2.389

23. Platt CD, Ma JK, Chalouni C, Ebersold M, Bou-Reslan H, Carano RA, et al. Mature dendritic cells use endocytic receptors to capture and present antigens. Proc Natl Acad Sci USA (2010) 107(9):4287-92. doi: 10.1073/ pnas.0910609107

24. Maree AF, Komba M, Dyck C, Labecki M, Finegood DT, Edelstein-Keshet L. Quantifying macrophage defects in type 1 diabetes. J Theor Biol (2005) 233 (4):533-51. doi: 10.1016/j.jtbi.2004.10.030

25. Kaplan G, Nusrat A, Witmer MD, Nath I, Cohn ZA. Distribution and turnover of Langerhans cells during delayed immune responses in human skin. J Exp Med (1987) 165(3):763-76. doi: 10.1084/jem.165.3.763

26. Di Girolamo W, Coronato S, Portiansky E, Laguens G. Profile of immune cells in lymph nodes draining human malignant tumors. Med (B Aires) (2008) 68(6):423-7.

27. Dupuis M, McDonald DM, Ott G. Distribution of adjuvant MF59 and antigen gD2 after intramuscular injection in mice. Vaccine (1999) 18(56):434-9. doi: 10.1016/s0264-410x(99)00263-7

28. Leeman M, Choi J, Hansson S, Storm MU, Nilsson L. Proteins and antibodies in serum, plasma, and whole blood-size characterization using asymmetrical flow field-flow fractionation (AF4). Anal Bioanal Chem (2018) 410(20):4867-73. doi: 10.1007/s00216-018-1127-2

29. Delamarre L, Holcombe H, Mellman I. Presentation of exogenous antigens on major histocompatibility complex (MHC) class I and MHC class II molecules is differentially regulated during dendritic cell maturation. $J$ Exp Med (2003) 198(1):111-22. doi: 10.1084/jem.20021542

30. Henrickson SE, Mempel TR, Mazo IB, Liu B, Artyomov MN, Zheng H, et al. $\mathrm{T}$ cell sensing of antigen dose governs interactive behavior with dendritic cells and sets a threshold for T cell activation. Nat Immunol (2008) 9(3):28291. doi: $10.1038 /$ ni1559

31. Wilson NS, El-Sukkari D, Villadangos Je A. Dendritic cells constitutively present self antigens in their immature state in vivo and regulate antigen presentation by controlling the rates of MHC class II synthesis and endocytosis. Blood. (2004) 103(6):2187-95. doi: 10.1182/blood-2003-082729

32. Mandl JN, Liou R, Klauschen F, Vrisekoop N, Monteiro Ja o P, Yates AJ, et al. Quantification of lymph node transit times reveals differences in antigen surveillance strategies of naive CD4+ and CD8+ T cells. Proc Natl Acad Sci (2012) 109(44):18036-41. doi: 10.1073/pnas.1211717109

33. Rubtsov YP, Niec RE, Josefowicz S, Li L, Darce J, Mathis D, et al. Stability of the regulatory T cell lineage in vivo. Science (2010) 329(5999):1667-71. doi: 10.1126/science.1191996

34. Catron DM, Itano AA, Pape KA, Mueller DL, Jenkins MK. Visualizing the first $50 \mathrm{hr}$ of the primary immune response to a soluble antigen. Immunity. (2004) 21(3):341-7. doi: 10.1016/j.immuni.2004.08.007
35. Pittet MJ, Valmori D, Dunbar PR, Speiser DE, Lienard D, Lejeune F, et al. High frequencies of naive Melan-A/MART-1-specific CD8+ T cells in a large proportion of human histocompatibility leukocyte antigen (HLA)-A2 individuals. J Exp Med (1999) 190(5):705-16. doi: 10.1084/jem.190.5.705

36. Williams H, Sarapata E, Caldwell T, dePillis L. Mathematical modeling of regulatory $\mathrm{T}$ cell effects on renal cell carcinoma treatment. Discrete Continuous Dyn Syst Ser B (2013) 18: (4):915-43. doi: 10.3934/dcdsb.2013.18.915

37. Speiser DE, Colonna M, Ayyoub M, Cella M, Pittet MJ, Batard P, et al. The activatory receptor $2 \mathrm{~B} 4$ is expressed in vivo by human CD8+ effector alpha beta T cells. J Immunol (2001) 167(11):6165-70. doi: 10.4049/jimmunol.167.11.6165

38. Homann D, Teyton L, Oldstone MBA. Differential regulation of antiviral Tcell immunity results in stable CD8+ but declining CD4+ T-cell memory. Nat Med (2001) 7(8):913-9. doi: 10.1038/90950

39. Valmori D, Merlo A, Souleimanian NE, Hesdorffer CS, Ayyoub M. A peripheral circulating compartment of natural naive CD4 Tregs. J Clin Invest (2005) 115(7):1953-62. doi: 10.1172/JCI23963

40. Litjens NH, Boer K, Zuijderwijk JM, Klepper M, Peeters AM, Prens EP, et al. Allogeneic Mature Human Dendritic Cells Generate Superior Alloreactive Regulatory T Cells in the Presence of IL-15. J Immunol (2015) 194(11):528293. doi: 10.4049/jimmunol.1402827

41. Geiger R, Duhen T, Lanzavecchia A, Sallusto F. Human naive and memory $\mathrm{CD} 4+\mathrm{T}$ cell repertoires specific for naturally processed antigens analyzed using libraries of amplified T cells. J Exp Med (2009) 206(7):1525-34. doi: 10.1084/jem.20090504

42. Murali-Krishna K, Altman JD, Suresh M, Sourdive DJ, Zajac AJ, Miller JD, et al. Counting antigen-specific CD8 T cells: a reevaluation of bystander activation during viral infection. Immunity (1998) 8(2):177-87. doi: 10.1016/ s1074-7613(00)80470-7

43. Hellerstein M, Hanley MB, Cesar D, Siler S, Papageorgopoulos C, Wieder E, et al. Directly measured kinetics of circulating T lymphocytes in normal and HIV-1-infected humans. Nat Med (1999) 5(1):83-9. doi: 10.1038/4772

44. Obst R. Timing T cell priming cycling. Front Immunol (2015) 6:563. doi: 10.3389/fimmu.2015.00563

45. Butz EA, Bevan MJ. Massive expansion of antigen-specific CD8+ T cells during an acute virus infection. Immunity (1998) 8(2):167-75. doi: 10.1016/ s1074-7613(00)80469-0

46. Gerlach C, Rohr JC, Perie L, van Rooij N, van Heijst JW, Velds A, et al. Heterogeneous differentiation patterns of individual CD8+ T cells. Science (2013) 340(6132):635-9. doi: 10.1126/science.1235487

47. Buchholz VR, Flossdorf M, Hensel I, Kretschmer L, Weissbrich B, Graf P, et al. Disparate individual fates compose robust CD8+ T cell immunity. Science (2013) 340(6132):630-5. doi: 10.1126/science.1235454

48. Lotze MT, Matory YL, Ettinghausen SE, Rayner AA, Sharrow SO, Seipp CA, et al. In vivo administration of purified human interleukin 2. II. Half life, immunologic effects, and expansion of peripheral lymphoid cells in vivo with recombinant IL 2. J Immunol (1985) 135(4):2865-75.

49. Borghans J AM, Tesselaar K, de Boer RJ. Current best estimates for the average lifespans of mouse and human leukocytes: reviewing two decades of deuterium-labeling experiments. Immunol Rev (2018) 285(1):233-48. doi: 10.1111/imr.12693

50. Vukmanovic-Stejic M, Zhang Y, Cook JE, Fletcher JM, McQuaid A, Masters JE, et al. Human CD4+ CD25hi Foxp3+ regulatory $\mathrm{T}$ cells are derived by rapid turnover of memory populations in vivo. J Clin Invest (2006) 116 (9):2423-33. doi: 10.1172/JCI28941

51. Carlson JA. Tumor doubling time of cutaneous melanoma and its metastasis. Am J Dermatopathol (2003) 25:291-9. doi: 10.1097/00000372200308000-00003

52. Eskelin S, Pyrhonen S, Summanen P, Hahka-Kemppinen M, Kivela T. Tumor doubling times in metastatic malignant melanoma of the uvea: tumor progression before and after treatment. Ophthalmology. (2000) 107:1443-9. doi: 10.1016/S0161-6420(00)00182-2

53. Ollila DW, Stern SL, Morton DL. Tumor doubling time: a selection factor for pulmonary resection of metastatic melanoma. J Surg Oncol (1998) 69:206-11. doi: 10.1002/(SICI)1096-9098(199812)69:4<206::AIDJSO3>3.0.CO;2-N

54. Sarapata EA, de Pillis LG. A comparison and catalog of intrinsic tumor growth models. Bull Math Biol (2014) 76(8):2010-24. doi: 10.1007/s11538014-9986-y 
55. Carreno BM, Hansen TH. Exogenous peptide ligand influences the expression and half-life of free HLA class I heavy chains ubiquitously detected at the cell surface. Eur J Immunol (1994) 24(6):1285-92. doi: 10.1002/eji.1830240607

56. Christinck ER, Luscher MA, Barber BH, Williams DB. Peptide binding to class I MHC on living cells and quantitation of complexes required for CTL lysis. Nature. (1991) 352(6330):67-70. doi: 10.1038/352067a0

57. Coffman RL, Sher A, Seder RA. Vaccine adjuvants: putting innate immunity to work. Immunity. (2010) 33(4):492-503. doi: 10.1016/j.immuni.2010.10.002

58. Gardner A, Ruffell B. Dendritic Cells and Cancer Immunity. Trends Immunol (2016) 37(12):855-65. doi: 10.1016/j.it.2016.09.006

59. Mellman I, Steinman RM. Dendritic cells: specialized and regulated antigen processing machines. Cell. (2001) 106(3):255-8. doi: 10.1016/S0092-8674 (01)00449-4

60. Trombetta ES, Mellman I. Cell biology of antigen processing in vitro and in vivo. Annu Rev Immunol (2005) 23:975-1028. doi: 10.1146/annurev.immunol.22. 012703.104538

61. Steinman RM, Hawiger D, Nussenzweig MC. Tolerogenic dendritic cells. Annu Rev Immunol (2003) 21:685-711. doi: 10.1146/annurev.immunol.21. 120601.141040

62. De Smedt T, Pajak B, Muraille E, Lespagnard L, Heinen E, De Baetselier P, et al. Regulation of dendritic cell numbers and maturation by lipopolysaccharide in vivo. J Exp Med (1996) 184(4):1413-24. doi: 10.1084/jem.184.4.1413

63. Benson MJ, Pino-Lagos K, Rosemblatt M, Noelle RJ. All-trans retinoic acid mediates enhanced $\mathrm{T}$ reg cell growth, differentiation, and gut homing in the face of high levels of co-stimulation. J Exp Med (2007) 204(8):1765-74. doi: 10.1084/jem.20070719

64. Dons EM, Raimondi G, Cooper DK, Thomson AW. Induced regulatory T cells: mechanisms of conversion and suppressive potential. Hum Immunol (2012) 73(4):328-34. doi: 10.1016/j.humimm.2011.12.011

65. Alexander-Miller MA, Leggatt GR, Berzofsky JA. Selective expansion of high- or low-avidity cytotoxic $\mathrm{T}$ lymphocytes and efficacy for adoptive immunotherapy. Proc Natl Acad Sci (1996) 93(9):4102-7. doi: 10.1073/pnas.93.9.4102

66. Bullock TNJ, Mullins DW, Colella TA, Engelhard VH. Manipulation of Avidity to Improve Effectiveness of Adoptively Transferred CD8+ T Cells for Melanoma Immunotherapy in Human MHC Class I-Transgenic Mice. J Immunol (2001) 167(10):5824-31. doi: 10.4049/jimmunol.167.10.5824

67. Kedl RM, Schaefer BC, Kappler JW, Marrack P. T cells down-modulate peptide-MHC complexes on APCs in vivo. Nat Immunol (2002) 3(1):27. doi: 10.1038/ni742

68. Kedl RM, Rees WA, Hildeman DA, Schaefer B, Mitchell T, Kappler J, et al. T cells compete for access to antigen-bearing antigen-presenting cells. J Exp Med (2000) 192(8):1105-14. doi: 10.1084/jem.192.8.1105

69. Kroger CJ, Amoah S, Alexander-Miller MA. Cutting edge: Dendritic cells prime a high avidity CTL response independent of the level of presented antigen. J Immunol (2008) 180(9):5784-8. doi: 10.4049/jimmunol.180.9.5784

70. Sandberg JK, Franksson L, Sundback J, Michaelsson J, Petersson M, Achour A, et al. T cell tolerance based on avidity thresholds rather than complete deletion allows maintenance of maximal repertoire diversity. J Immunol (2000) 165(1):25-33. doi: 10.4049/jimmunol.165.1.25

71. van den Boorn JG, Le Poole IC, Luiten RM. T-cell avidity and tuning: the flexible connection between tolerance and autoimmunity. Int Rev Immunol (2006) 25(3-4):235-58. doi: 10.1080/08830180600743081

72. Vigano S, Utzschneider DT, Perreau M, Pantaleo G, Zehn D, Harari A. Functional avidity: a measure to predict the efficacy of effector T cells? Clin Dev Immunol (2012) 2012:153863. doi: 10.1155/2012/153863

73. Bauer J, Bahmer FA, Worl J, Neuhuber W, Schuler G, Fartasch M. A strikingly constant ratio exists between Langerhans cells and other epidermal cells in human skin. A stereologic study using the optical disector method and the confocal laser scanning microscope. J Invest Dermatol (2001) 116 (2):313-8. doi: 10.1046/j.1523-1747.2001.01247.x

74. Ferdousi M, Romanchuk K, Mah JK, Virtanen H, Millar C, Malik RA, et al. Early corneal nerve fibre damage and increased Langerhans cell density in children with type 1 diabetes mellitus. Sci Rep (2019) 9(1):8758. doi: 10.1038/ s41598-019-45116-Z

75. Haller Hasskamp J, Zapas JL, Elias EG. Dendritic cell counts in the peripheral blood of healthy adults. Am J Hematol (2005) 78(4):314-5. doi: 10.1002/ajh.20296
76. Walseng E, Furuta K, Bosch B, Weih KA, Matsuki Y, Bakke O, et al. Ubiquitination regulates MHC class II-peptide complex retention and degradation in dendritic cells. Proc Natl Acad Sci USA (2010) 107 (47):20465-70. doi: 10.1073/pnas.1010990107

77. Gannon PO, Baumgaertner P, Huber A, Iancu EM, Cagnon L, Abed Maillard S, et al. Rapid and Continued T-Cell Differentiation into Longterm Effector and Memory Stem Cells in Vaccinated Melanoma Patients. Clin Cancer Res (2017) 23(13):3285-96. doi: 10.1158/1078-0432.CCR-161708

78. Murphy K. Janeway's Immunobiology (Immunobiology: The Immune System (Janeway)). New York, New York, USA: Garland Science (2011).

79. Beers MH, Berkow R, Bogin RM, Fletcher AJ, Nace BA, Moy DE, et al. The Merck manual of diagnosis and therapy. Whitehouse Station, NJ: Merck (1999). Available at: http://www.merck.com/pubs/mmanual/.

80. Schreibelt G, Bol KF, Westdorp H, Wimmers F, Aarntzen EH, Duiveman-de Boer T, et al. Effective Clinical Responses in Metastatic Melanoma Patients after Vaccination with Primary Myeloid Dendritic Cells. Clin Cancer Res (2016) 22(9):2155-66. doi: 10.1158/1078-0432.CCR-15-2205

81. Verdijk P, Aarntzen EH, Lesterhuis WJ, Boullart AC, Kok E, van Rossum MM, et al. Limited amounts of dendritic cells migrate into the T-cell area of lymph nodes but have high immune activating potential in melanoma patients. Clin Cancer Res (2009) 15(7):2531-40. doi: 10.1158/1078-0432.CCR-08-2729

82. Camacho LH. CTLA-4 blockade with ipilimumab: biology, safety, efficacy, and future considerations. Cancer Med (2015) 4(5):661-72. doi: 10.1002/ cam4.371

83. Mahoney KM, Freeman GJ, McDermott DF. The Next Immune-Checkpoint Inhibitors: PD-1/PD-L1 Blockade in Melanoma. Clin Ther (2015) 37(4):764-82. doi: 10.1016/j.clinthera.2015.02.018

84. Ott PA, Hodi FS, Robert C. CTLA-4 and PD-1/PD-L1 blockade: new immunotherapeutic modalities with durable clinical benefit in melanoma patients. Clin Cancer Res (2013) 19(19):5300-9. doi: 10.1158/10780432.CCR-13-0143

85. Bertrand A, Kostine M, Barnetche T, Truchetet ME, Schaeverbeke T. Immune related adverse events associated with anti-CTLA-4 antibodies: systematic review and meta-analysis. BMC Med (2015) 13:211. doi: 10.1186/ s12916-015-0455-8

86. Corsello SM, Barnabei A, Marchetti P, De Vecchis L, Salvatori R, Torino F. Endocrine side effects induced by immune checkpoint inhibitors. J Clin Endocrinol Metab (2013) 98(4):1361-75. doi: 10.1210/jc.2012-4075

87. Gelao L, Criscitiello C, Esposito A, Goldhirsch A, Curigliano G. Immune checkpoint blockade in cancer treatment: a double-edged sword cross-targeting the host as an "innocent bystander". Toxins (Basel) (2014) 6(3):914-33. doi: 10.3390/toxins6030914

88. Andersson B. Studies on the regulation of avidity at the level of the single antibody-forming cell. The effect of antigen dose and time after immunization. J Exp Med (1970) 132(1):77-88. doi: 10.1084/jem.132.1.77

89. Billeskov R, Lindenstrom T, Woodworth J, Vilaplana C, Cardona PJ, Cassidy JP, et al. High Antigen Dose Is Detrimental to Post-Exposure Vaccine Protection against Tuberculosis. Front Immunol (2017) 8:1973. doi: 10.3389/ fimmu.2017.01973

90. Carretero-Iglesia L, Couturaud B, Baumgaertner P, Schmidt J, Maby-El Hajjami H, Speiser DE, et al. High Peptide Dose Vaccination Promotes the Early Selection of Tumor Antigen-Specific CD8 T-Cells of Enhanced Functional Competence. Front Immunol (2019) 10:3016. doi: 10.3389/ fimmu.2019.03016

91. Narayan S, Choyce A, Fernando GJ, Leggatt GR. Secondary immunisation with high-dose heterologous peptide leads to CD8 T cell populations with reduced functional avidity. Eur J Immunol (2007) 37(2):406-15. doi: 10.1002/eji.200535688

92. Oh S, Hodge JW, Ahlers JD, Burke DS, Schlom J, Berzofsky JA. Selective induction of high avidity CTL by altering the balance of signals from APC. J Immunol (2003) 170(5):2523-30. doi: 10.4049/jimmunol.170.5.2523

93. Della Bella S, Gennaro M, Vaccari M, Ferraris C, Nicola S, Riva A, et al. Altered maturation of peripheral blood dendritic cells in patients with breast cancer. Br J Cancer (2003) 89(8):1463-72. doi: 10.1038/sj.bjc.6601243

94. Hirooka S, Yanagimoto H, Satoi S, Yamamoto T, Toyokawa H, Yamaki S, et al. The role of circulating dendritic cells in patients with unresectable pancreatic cancer. Anticancer Res (2011) 31(11):3827-34. 
95. Pinzon-Charry A, Ho CS, Maxwell T, McGuckin MA, Schmidt C, Furnival C, et al. Numerical and functional defects of blood dendritic cells in early- and latestage breast cancer. Br J Cancer (2007) 97(9):1251-9. doi: 10.1038/sj.bjc.6604018

96. Pedersen SR, Sorensen MR, Buus S, Christensen JP, Thomsen AR. Comparison of vaccine-induced effector CD8 T cell responses directed against self- and nonself-tumor antigens: implications for cancer immunotherapy. J Immunol (2013) 191(7):3955-67. doi: 10.4049/jimmunol.1300555

97. Carreno BM, Magrini V, Becker-Hapak M, Kaabinejadian S, Hundal J, Petti $\mathrm{AA}$, et al. Cancer immunotherapy. A dendritic cell vaccine increases the breadth and diversity of melanoma neoantigen-specific T cells. Science (2015) 348(6236):803-8. doi: 10.1126/science.aaa3828

98. Ott PA, Hu Z, Keskin DB, Shukla SA, Sun J, Bozym DJ, et al. An immunogenic personal neoantigen vaccine for patients with melanoma. Nature (2017) 547(7662):217-21. doi: 10.1038/nature22991

99. Sahin U, Derhovanessian E, Miller M, Kloke BP, Simon P, Lower M, et al. Personalized RNA mutanome vaccines mobilize poly-specific therapeutic immunity against cancer. Nature (2017) 547(7662):222-6. doi: 10.1038/ nature23003

100. Schumacher T, Bunse L, Pusch S, Sahm F, Wiestler B, Quandt J, et al. A vaccine targeting mutant IDH1 induces antitumour immunity. Nature (2014) 512(7514):324-7. doi: 10.1038/nature13387

101. Wilgenhof S, Corthals J, Heirman C, van Baren N, Lucas S, Kvistborg P, et al. Phase II Study of Autologous Monocyte-Derived mRNA Electroporated Dendritic Cells (TriMixDC-MEL) Plus Ipilimumab in Patients With Pretreated Advanced Melanoma. J Clin Oncol (2016) 34(12):1330-8. doi: 10.1200/JCO.2015.63.4121

102. Kantoff PW, Higano CS, Shore ND, Berger ER, Small EJ, Penson DF, et al. Sipuleucel-T immunotherapy for castration-resistant prostate cancer. $N$ Engl J Med (2010) 363(5):411-22. doi: 10.1056/NEJMoa1001294

103. Mastelic-Gavillet B, Balint K, Boudousquie C, Gannon PO, Kandalaft LE. Personalized Dendritic Cell Vaccines-Recent Breakthroughs and Encouraging Clinical Results. Front Immunol (2019) 10:766. doi: 10.3389/fimmu.2019.00766

104. Liu H, Moynihan KD, Zheng Y, Szeto GL, Li AV, Huang B, et al. Structurebased programming of lymph-node targeting in molecular vaccines. Nature (2014) 507(7493):519-22. doi: 10.1038/nature12978

105. Anandasabapathy N, Breton G, Hurley A, Caskey M, Trumpfheller C, Sarma P, et al. Efficacy and safety of CDX-301, recombinant human Flt3L, at expanding dendritic cells and hematopoietic stem cells in healthy human volunteers. Bone Marrow Transplant (2015) 50(7):924-30. doi: 10.1038/ bmt.2015.74

106. Maraskovsky E, Daro E, Roux E, Teepe M, Maliszewski CR, Hoek J, et al. In vivo generation of human dendritic cell subsets by Flt3 ligand. Blood (2000) 96(3):878-84. doi: 10.1182/blood.V96.3.878.015k15_878_884

107. Pulendran B, Banchereau J, Burkeholder S, Kraus E, Guinet E, Chalouni C, et al. Flt3-ligand and granulocyte colony-stimulating factor mobilize distinct human dendritic cell subsets in vivo. J Immunol (2000) 165(1):566-72. doi: 10.4049/jimmunol.165.1.566

108. Obeid J, Hu Y, Slingluff CLJr. Vaccines, Adjuvants, and Dendritic Cell Activators-Current Status and Future Challenges. Semin Oncol (2015) 42 (4):549-61. doi: 10.1053/j.seminoncol.2015.05.006

109. Palucka K, Banchereau J, Mellman I. Designing vaccines based on biology of human dendritic cell subsets. Immunity. (2010) 33(4):464-78. doi: 10.1016/ j.immuni.2010.10.007

110. Lever M, Maini PK, van der Merwe PA, Dushek O. Phenotypic models of T cell activation. Nat Rev Immunol (2014) 14(9):619-29. doi: 10.1038/nri3728

111. Irving M, Zoete V, Hebeisen M, Schmid D, Baumgartner P, Guillaume P, et al. Interplay between $\mathrm{T}$ cell receptor binding kinetics and the level of cognate peptide presented by major histocompatibility complexes governs CD8+ T cell responsiveness. J Biol Chem (2012) 287(27):23068-78. doi: 10.1074/jbc.M112.357673

112. Naeher D, Daniels MA, Hausmann B, Guillaume P, Luescher I, Palmer E. A constant affinity threshold for T cell tolerance. J Exp Med (2007) 204 (11):2553-9. doi: 10.1084/jem.20070254

Conflict of Interest: The authors declare that the research was conducted in the absence of any commercial or financial relationships that could be construed as a potential conflict of interest.

Copyright (c) 2020 Kumbhari, Egelston, Lee and Kim. This is an open-access article distributed under the terms of the Creative Commons Attribution License (CC BY). The use, distribution or reproduction in other forums is permitted, provided the original author(s) and the copyright owner(s) are credited and that the original publication in this journal is cited, in accordance with accepted academic practice. No use, distribution or reproduction is permitted which does not comply with these terms. 